\title{
Broadcast Programming and Strategies in the Spanish TV Duopoly System: A Comparative Analysis on Atresmedia and Mediaset (2013-2019)
}

\author{
Joaquín Sotelo-González \\ Complutense University of Madrid (Spain) \\ Javier Sierra-Sánchez \\ Complutense University of Madrid (Spain) \\ Francisco Cabezuelo-Lorenzo \\ Complutense University of Madrid (Spain)
}

Over the last decade, the private television market in Spain has gone through a paradigmatic model of duopoly between two large corporations, Atresmedia and Mediaset, both forged out of two major mergers: that of Telecinco with Cuatro, and that of Antena 3 with La Sexta. We intended to analyze the change that the private television sector has undergone in our country since that double merger and how the content and audiences of the four channels have evolved. We resorted to a methodological triangulation of his- torical-systemic review, content analysis and comparative method. One of the most interesting conclusions drawn from the investigation has been the discovery that Mediaset has turned Cuatro into an almost mimetic channel and subsidiary of Telecinco, while Atresmedia has largely respected the differentiation of its two main channels: Antena 3 and La Sexta TV.

Keywords: Television, audiences, Atresmedia, Mediaset, programming, Duopoly.

\footnotetext{
A ntena 3, Telecinco and Canal Plus were the first private TV operators in Spain. They marked the beginning of the gradual audience division in Spain (Polo, 2017). The birth of generalist private stations, specially Antena 3 and Telecinco, was a turning point in the market (Bustamante, 2013; Contreras and Palacio, 2001). New genres, formats and styles came up, giving rise both to a range of possibilities and a war for audiences (Villagrasa, 2011). This war escalated with the boom of theme channels brought by deploying terrestrial
} 
digital television (TDT) in place of analogue television (Marzal, 2007) and the arrival of Cuatro, in 2005, and La Sexta, in 2006. Intense competition between operators in as limited a market as the Spanish one, and in an oligopolization prone sector (Cuilenburg, 2000), led to a series of mergers resulting in the creation of Atresmedia and Mediaset, currently the two largest TV groups.

An analysis of the comparison between programmings of the four channels of Spain's largest operators, Mediaset and Atresmedia, was carried out. These operators were established following the merges of Telecinco/Cuatro, and Antena 3/La Sexta. Such alliances supposed a milestone in Spanish TV history. They set a before and after in Spain's audiovisual picture (Sotelo, 2017a), now dominated by those large communication groups, both in terms of audience (Barlovento Comunicación, 2019) and advertising investment (InfoAdex, 2020).

The first private TV station to kick off in Spain was Antena 3. It began its regular broadcasts on January 25, 1990 (Bustamante, 2013). From the beginning, it was different in style compared with Telecinco. It wasn't until 1992 that Antena 3 took off after incorporating renowned professionals like Mercedes Milá or Jesús Hermida. In 1993 the most successful formats was El gran juego de la oca, presented by Emilio Aragón. In 1996 there was a content quality leap, starting with emblematic shows like Sorpresa sorpresa or Espejo público, to which other hits such as Furor and Sabor a ti would later be added. Antena 3 found its strength in fiction, producing successful shows like Farmacia de guardia, Aquí no hay quien viva, Física o química, El tiempo entre costuras and Velvet, to name a few. The only great involvement Antena 3 had in the gossip news field was with ¿Dónde estás, corazón? (DEC), initially on Friday primetime, from July 2003, when it had a mean 1,9 million viewers (19.8\% screen share) throughout its eight years of history, until Telecinco began to broadcast Sálvame deluxe in the same slot.

Telecinco, officially launched on March 3, 1990, did not take long to find the mark that would quickly set it apart from TVE and Antena 3 within the Spanish TV scene (Artero-Muñoz, 2007). To achieve this, it drew inspiration from the Italian matrix and sister model: Canale 5. Not only did it place importance on the content, but also on how it was delivered to the audience through an innovative production (Pedrero, 2008). Telecinco soon stood out in the entertainment field particularly, though it did not want to be left behind in producing fiction series. In 2000, Telecinco found what would be its flagship and cornerstone even to this day: the premiere of the first edition of Gran Hermano (Big Brother), whose undeniable success opened the door for reality shows in Spain. This format would make Telecinco the undisputed lead with slots like Sobrevivientes, Hotel Glam or La isla de las tentaciones. Talent shows also identify Telecinco, with shows such as La Voz (The Voice), La Voz Kids, Got Talent, Factor X or Operación Triunfo. It is also Spain's most criticized network by a portion of society, partly due to the great abundance of controversy-based formats, commonly labeled as "trash TV" (Cubells, 2003; Soto, 2005; Íñigo, 2013). In spite of that, ratings and accountability data (it is publicly listed in Ibex 35) show that its model is tremendously effective, profitable, and fidelity-inducing in viewers (Mediaset España, 2018). 
Cuatro's proposal, Prisa's great gamble on the audiovisual sector, burst in with impact thanks to a marked visual identity and some original and groundbreaking content for the time (González-Oñate, 2008). From the beginning the reputed journalist Iñaki Gabilondo was the main reference with programmes where the street and its pedestrians were the main characters, with shows like Callejeros or Supernanny. Initially, the channel was also interested in social chronicles and gossip, with Channel $n^{-} 4$ making up its afternoons until its cancellation in 2008. For the late-night, Cuatro gambled on Eva Hache and her Noche hache, following the typical American late-night show. Ten months after its birth, in 2006, Cuatro also experimented producing in the morning slot by taking one of its greater risks, Las mañanas de Cuatro, suddenly cancelled in June 2018.

Cuatro gave birth to another breakthrough format also in 2006, El hormiguero. This was the channel's banner until Antena 3 acquired the rights for its weekly access primetime. The world of realities and talent shows was also explored by Cuatro soon after its conception, with products such as Supermodelo 2006; Fama, ¡A bailar!; Factor X or Pekín express. As to fiction, Cuatro offered viewers national series like Los simuladores, Chicas en la ciudad, Cuenta atrás or Hay alguien ahí. However, it abandoned the national production of fiction after merging with Telecinco. Nevertheless, it was in foreign fiction where Cuatro found its best allies, with hits like House, Entre fantasmas (Ghost Whisperer), Anatomía de Grey (Grey's Anatomy), Queer as folk, Medium, Kyle XY, Castle, Los pilares de la Tierra (The Pillars of the Earth), Perdidos (Lost) or Homeland. Other shows such as 21 dias, Desafio extremo or Cuarto milenio, and competitions like Password or Soy el que más sabe de televisión del mundo have been part of Cuatro's identity throughout its history.

On November 27th, 2005, the Government made public the ruling that conceded the fourth analog channel to the Sociedad gestora de inversiones audiovisuales La Sexta. From the first moment, La Sexta adopted humor as the main ensign. The two formats that gave wings to the channel, and ended up becoming its unmistakable hallmarks, were Sé lo que hicisteis, up to 2011, and El intermedio, until now, also with Caiga quien caiga and Buenafuente. If La Sexta placed its bets on anything, besides humor, it was on sports. It acquired the broadcasting rights of 2006's World cup, several editions of Eurobasket, 2010's Basketball world cup, and Formula 1 between 2009 and 2013.

The occasional reality and successful factual shows are also found in La Sexta's history: Pesadilla en la cocina. Foreign series like Los Soprano (The Sopranos), Prison Break, Bones, El mentalista (The Mentalist), Numb3rs, The walking dead, Person of interest, Juego de tronos (Game of Thrones) and True detective also found their spot in La Sexta. In the last years, as TVE has lost credibility due to News Programs being accused of manipulation and bias (Sotelo, 2017b), La Sexta has taken advantage of weaknesses in the public service to become an information reference. News, discussion and debate slots, like Al rojo vivo, Más vale tarde, El objetivo de Ana Pastor, La Sexta noche or Salvados became fundamental in its programming. This also shows that news and politics are also of interest to the audience. Pujadas and Oliva (2007) remark that both Cuatro and La Sexta were born with significant differences compared with other private channels. 
Their strategies into the TV market set them apart from existing channels, and also from the first public channels. This brought them closer to children/ youth, educational, and sports content. These channels very much approached the concept of quality TV, that is, debate, critical thinking, entertainment, intelligent humor, and cultural content-generating television (Pérez-Tornero, 2005; Medina-Laverón, 2006).

\section{THEORETICAL AND CONCEPTUAL FRAMEWORKS}

This research is contextualized in recent history and market structure studies on Spanish television in the past 10 years (Albújar, 2018), as well as studies on television programming theories and techniques (Contreras and Palacio, 2001; Pérez-Tornero, 2005; Medina, 2006).

The regulatory framework was also found fitting for the merges. Approved laws in Spain made transit-through-crisis easy for private communication groups. This allowed the gathering of media for purely marketing purposes. The bases for such a controlled opening to Spanish TV liberalization were laid on 2010 with a new general law for audiovisual communication (LGCA in Spanish). It established the conditions for operator merges, quote: Networks involved in a subsequent merge cannot comprise more than $27 \%$ share during the year prior to the merge - that limit can be surpassed afterward- neither can they comprise more than two multiplex (that is 4 channels in this case). In addition, at least three different TV carriers must exist. The dominating position of private operators in that law's negotiations should not be forgotten.

The appearance of Cuatro and La Sexta, along with the arrival of TDT, revolutionized the Spanish audiovisual sector. Going from six to twenty channels seriously affected ratings (Cavaller, Vila, and Roca, 2013) and consequently, all networks saw their profits decimated. A decrease in ratings for Antena 3 and Telecinco ensued (Barlovento Comunicación, 2006 and et seq.), causing a harsh setback for these two private networks. Given a series of circumstances, especially the economic crisis from 2007 onward, Cuatro and La Sexta were soon in serious business viability difficulties (Sotelo-González, 2017a; Cabezuelo, 2013). Thus, the decision to unify affairs to optimize results was not made to wait. The merges were the result of studies carried out on new strategies by Telecinco and Antena 3 so as to continue dominating while not losing their privileged standings (Gómez-Pérez, Navarrete, and Pérez-Rufí, 2013). After the mergers, Mediaset and Atresmedia formed a duopoly in Spanish open TV, controlling 88\% of advertising (InfoAdex, 2012) and 54\% of screen share (Barlovento Comunicación, 2012). That season Mediaset's network got a $28.1 \%$ share while Atresmedia ended up second with $25.8 \%$. In comparison, the state corporation RTVE only got $18.9 \%$. Vocento, $4.4 \%$ audience, and Unidad editorial, 3.2\%. (InfoAdex, 2012; Barlovento Comunicación, 2012).

This research pivots on a TV programming comparative study. As Arana (2011: 65) points out to program in television is to articulate a series of contents to build a channel's structure. It is a strategy to seduce the audience by 
generating a drag effect, guaranteeing the network's profitability (Cortés-Lahera, 2001: 116). It is not enough, however, to incorporate contents destined to a potential audience. A global TV homogeneity should be aimed at, preventing slots' isolation from one another (Zunzunegui, 2003: 201).

In a channel's programming grid all kinds of genres, durations and targets are combined, acquiring a meaning and logic that goes beyond each individual program's (Arana, 2011: 71). Contreras and Palacio (2001: 169) suggest that grid stability is determined, at least in generalist TV, by programming adjusted to certain time slots. These must be stable and long-lasting, independently of day or season. This fixed programming consolidates the channel's concept. Television programming is linked to the customs, habits, and culture of the society it is broadcast to (Contreras and Palacio, 2001). Programs broadcast by a channel allow viewers to create a mental picture of it, hence making the channel easily identifiable. When coming up with new programs, it is necessary to outline their style so that brand/product identity can be created (GonzálezOñate, 2008: 131).

The media are largely responsible for the formation of the image that is created of them among the public (Losada, 2002). The corporate image of the company must correspond to its identity, which constitutes a transcendental element for the construction of the public perception of the organization and, with it, of the brand (Galindo, 2004). Each television channel must "emphasize as much as possible a differential identity and brand" (Zubiaurre, 2009: 271) in order to solve the difficulties related to fragmentation and to gain a niche within the viewer's choice among the great competition of existing schedules. A channel as a television structure has more study entity than a simple television program or a set of them. The brand is one of the main elements of every television channel (Melgarejo and Rodríguez-Rosell, 2012: 40) and it becomes the most powerful weapon with which to position itself against other competitors (Mora-Figueroa, 2009). The brand image is an economic criterion because it also has an impact on increasing the audience, advertising or attracting specific audiences from population sectors. This brand image is also sometimes applied as a quality parameter of the channels and is achieved largely through programming (Ferrer, 2016: 67).

The standardized, acknowledged slots for Spanish TV industry are (VacaBerdayes, 2009): Early-morning (from 02:30 to 07:00); Morning (from 07:00 to 14:00), Early afternoon (from 14:00 to 17:00), Afternoon (from 17:00 to 20:30), Night1 [access and primetime] (from 20:30 to 24:00) and finally Night2 [late-night] (from 24:00 to 02:30). Cortés-Lahera (2001) identified four values TV shows must possess to obtain a positive response from the audience: 1) intrinsic value; 2) placement value; 3) strategic value and 4) economic value. The intrinsic value is related to the possibility of success of a grid known by the viewer. The placement value is related to the place a show occupies in a grid. The strategic, or contrast, value refers to the contrast between shows broadcast at the same time slot in competing channels. Lastly, the economic value pertains to a show's profitability with respect to its location in the week, time slot and place compared with a real competitor. 
190 RESEARCH DESIGN. OBJECTIVES AND METHODOLOGY

This research gravitates, from a historic point of view and according to the previous postulates, around three main objectives.

- O.1) To analyze how Antena 3, La Sexta, Telecinco, and Cuatro's contents and audiences have evolved since their respective mergers.

- O.2) To verify if programming creates brand identity, that is, if it allows viewers to recognize the network.

- O.3) To deliberate as to which of the four previous values precede in Spanish TV programming (Cortés-Lahera, 2001).

At the same time, this work pretends to answer the following research questions:

- Q.1) How have the four studied networks evolved, in terms of the programming/audience duo, in the past few years?

- Q.2) What kind of contents/formats have been offered by each of the studied channels?

- Q.3) Does this programming alone hold enough status to create brand identity?

- Q.4) According to Cortés' postulates (Cortés-Lahera, 2001), which value is most important to the audience when assessing a program?

A methodological triangulation is performed to achieve the objectives and answer the research questions. Firstly, a historical-systemic revision of the origins of the studied networks has been carried out. A holistic approach to the networks' programming and business strategies to the present day was employed. On the other hand, this work is based on a qualitative research approach (Rodríguez, Gil, and García, 1996), employing the document analysis technique (in this case, programming grids). The findings corresponding to TV programming of each channel were examined following content analysis (Martín, 1963; Krippendorff, 1990) and comparative analysis research procedures (Lijphart, 1971; Sartori, 1984).

In order to elaborate the analysis, the following aspects are defined:

A. Temporary period: a week of October of each year in the analyzed range (2013-2019) has been taken as sample. This is because October tends to mark the beginning of new TV seasons in Spain (Izquierdo-Castillo, 2016), while also having high monthly TV consumption (Barlovento Comunicación, 2019). The selected analysis period goes from the first year of competition between the two merged groups, to the present year.

B. Sample: Telecinco, Cuatro, Antena 3 and La Sexta's programming grids. This information was gathered from the channels' websites and, if not available, from Fórmula TV.

The main time slots were focused on. The late-night slot was left out as it is not competitive for operators. Same with the early-morning slot, since it is merely a recycling frame for both auditors (Kantar media) and operators. 
The programming between 09:00 and 00:00 was compared. Fixed news-programs frames were omitted (most of Early afternoon time) since they would warrant their own separate research. The highest and lowest audience values are given whenever possible, be it on its day of broadcast or throughout the week. The mean audience value is given whenever data is not available.

This research is largely based on data obtained from seven weeks' worth of analysis, which somehow limits the work. To make up for those limitations, the authors' knowledge of full seasons, and yearly audience data, were used as support.

C. Analysis units: shows, genres and formats, except news programs, from channels' grids.

D. Tools and sources: analyzed channel's websites, and audience data provided directly by Kantar media through Fórmula TV and Barlovento Comunicación.

Each channel's mean audience data were taken as reference to assess programs' success/functionality/non-functionality (Table 1). Programs lying on the mean or above are considered functional. Those below the mean are considered less/ non-functional.

Table 1. Yearly mean audience share of analyzed channels

\begin{tabular}{l|c|c|c|c|c|c|c} 
TV Station & $\mathbf{2 0 1 3}$ & $\mathbf{2 0 1 4}$ & $\mathbf{2 0 1 5}$ & $\mathbf{2 0 1 6}$ & $\mathbf{2 0 1 7}$ & $\mathbf{2 0 1 8}$ & $\mathbf{2 0 1 9}$ \\
\hline Antena 3 & $13.4 \%$ & $13.6 \%$ & $13.4 \%$ & $12.8 \%$ & $12.3 \%$ & $12.3 \%$ & $11.7 \%$ \\
\hline La Sexta & $6 \%$ & $7.2 \%$ & $7.4 \%$ & $7.1 \%$ & $6.7 \%$ & $6.9 \%$ & $7 \%$ \\
\hline Telecinco & $13.5 \%$ & $14.5 \%$ & $14.8 \%$ & $14.4 \%$ & $13.3 \%$ & $14.1 \%$ & $14.8 \%$ \\
\hline Cuatro & $6 \%$ & $6.7 \%$ & $7.2 \%$ & $6.5 \%$ & $6.2 \%$ & $6 \%$ & $5.3 \%$ \\
\hline
\end{tabular}

Source: Authors. From Kantar Media data provided by Barlovento Comunicación.

\section{RESULTS AND ANALYSIS}

From the four channels' 2013-2019 programming analysis (see Appendix) the following results are obtained. They were divided into blocks identified by groups name: Atresmedia (Antena 3 and La Sexta) and Mediaset (Telecinco and Cuatro). Style, weaknesses and strengths are described for each programming.

\section{Atresmedia Results}

One of Antena 3's most sensitive slots, up to 2017, were those of noon and Early afternoon. The 14:00-15:00 frame before the news program Antena 3 Noticias 1 is noteworthy. With a double run of Los Simpson, programmers tried to compete, everyday, with other morning offers. Ratings for this animation content were $7.2 \%$ and $14.9 \%$ for first and second episodes, respectively. The channel had a hard time getting rid of this, as it had stayed there for over 15 years and had become one of 
Antena 3's emblems. Additionally, it was estimated that Los Simpson had a drag effect on the audience to the next content (Antena 3 Noticias 1), given the influence of children on a family's remote. From Catalonia's referendum on October 1, 2017, onward, there was a demand of political news. This prompted the channel to stretch Espejo público, getting good results (peaking at 24\%), and to move La ruleta de la suerte to the animated series' place. Since then, the competition show (12.3\%-19\%) has widely exceeded the audience Los Simpson was obtaining in 2016 (7.2\%-12.4\%), also manging to dominate its slot daily.

Antena 3 has also managed to compete well in the last years in the Early afternoon and Early afternoon slots, with Amar es para siempre (10.4\%-15.7\%) and El secreto de puente viejo (9.6\%-20.9\%). Still, Antena 3 has not managed to reach the averages of its great competitor (Telecinco, with Sálvame diario [12\%-19.5\%] and Pasapalabra [14.5\%-21.5\%]) in the afternoon period. However, with ¡Boom! (12.5\%-14.4\%) Antena 3 has achieved a balance with its rival's competition show, Telecinco's Pasapalabra, which got cancelled beginning October 2019 for legal issues.

Regarding primetime, Antena 3 rarely leads over its direct rival. According to the latest global data (Barlovento Comunicación, 2013 and et seq.), Telecinco dominates primetime every day of the week (14.8\% versus $11.9 \%$ for Antena $3)$. The only products Antena 3 has been facing Telecinco with in the last few years are: 1) UEFA Champions League (31.1\%-34.7\%), always managing to prevail in its frame; 2) Tu cara me suena (11.8\%-22.1\%), able to dominate its frame on occasion, and 3) some weekend "blockbusters", especially on Sunday primetime.

Atresmedia's channel finds its main strength in the Saturday and Sunday afternoon period thanks to the three movies broadcast in its Multicine frame (10.5\%-20.9\%). As a relevant result, it can be underlined that some strong contents were transferred from La Sexta to Antena 3 ensuing their fusion in October 2012. Programs like Formula 1 allowed Antena 3 to grow nine tenths of share in 2013 with respect to the previous year. This placed Antena $3(13.4 \%)$ just behind Telecinco (13.5\%) as Spain's second most watched channel. It is worth noting the large audience contribution by three seasons of the UEFA Champions League (2015-2018), for which Antena 3 acquired the rights. Consequently, making up for the loss of these rights, Atresmedia hit the mark with its programming strategy and filled up the absence of soccer.

While reality and talent shows are proven as Telecinco's success, for Antena 3 this happens with fiction. Throughout the years Atresmedia's series like Velvet (17.3\%-20.1\%) and Mar de plástico (17.6\%-21.5\%), stand out with good ratings. Other series broadcast in different seasons (not analyzed), like El tiempo entre costuras, Sin identidad, Bajo sospecha, Vis a vis, La embajada, La catedral del mar or Tiempos de guerra, have also stood out. It is worth mentioning a case such as La casa de papel, where notwithstanding its underwhelming success on TV $(12.9 \%)$, its quality and technical production have brought prestige to the group. It increased international sales, especially after being commerciallized by Netflix.

Up to 2012 La Sexta was behind Cuatro in mean yearly audience (Barlovento Comunicación, 2013). The first time it reached Cuatro was in 2013 (Barlovento Comunicación, 2014), when both channels got a 6\% yearly share. In 2014 it 
got ahead of Cuatro (7.2\% and 6.7\%, respectively). From 2013 onward, La Sexta has beaten Cuatro in mean share each year. Unlike Cuatro, it was able to find its spot in Spanish TV with a well structured and defined programming. A TV model based on news, in-house produced entertainment, politics debates and humor. Areas in which Al rojo vivo, Salvados, La Sexta noche, Más vale tarde and El intermedio can be found as pillars.

The cited shows give stability to the channel, making it a reference in news and opinion for viewers, especially of certain ideological spectrum. Political and social news, as was the case with Catalonia's 1st of October 2017 referendum and its subsequent consequences, contribute heavily to La Sexta in terms of audience. This was clear from September 2017, when thanks to the Catalan issue it managed to exceed its previous month's share by 2.4 , obtaining a monthly rating of $9.1 \%$ in October. Al rojo vivo, its morning show, broke its record with a $16 \%$ mean screen share. Más vale tarde also had its best month with a mean 11.4\% share. La Sexta noche (11.7\%), El objetivo de Ana Pastor (11\%) and La Sexta columna (6.5\%-9.9\%) were also greatly benefited at the time. That week every single "Catalonia special" got very good ratings, particularly Al rojo vivo's morning Catalonia special on Saturday, October 21 (12.8\%-17.9\%).

In October 2019, when the verdict of the Catalan Process was made public, La Sexta returned as reference in news and opinion. Al rojo vivo obtained good ratings (11.1\%-20.8\%), above those of Espejo público (10.5\%-18.7\%), El programa de AR (19.5\%-21.3\%), and Ya es mediodía (12.5\%-14\%), being in the same time frame with the last two. This shows it has, once again, placed itself as a newsand-opinion reference thanks to a natural evolution of its contents. Furthermore, it has occupied a space TVE was not able to, setting itself apart from Antena 3 with a programming and reaction capacity worthy of public television, despite not being so.

A relative weakness of La Sexta is in its primetime slot. It broadcasts El intermedio (9\%-13.9\%) from Monday to Thursday with good results, but it generally follows with movies (3.8\%-14.3\%), with which it loses several points. For the last few years, there have been barely any shows that stand out in the primetime other than Pesadilla en la cocina (8.4\%-11.8\%), and other similar factual shows.

Weekend daytime (07:00-20:30) is this channel's greatest weakness. On Saturday and Sunday mornings it broadcasts repetitions with generally poor ratings (2.3\%-8.2\%). On weekend afternoons it has placed its bets on: 1$)$ movies and 2 nd division soccer (till 2014), with moderate data $(2.6 \%-9.8 \%)$; 2) moviesonly after losing soccer, also with moderate data (3.1\%-7.9\%) and 3) movies (3.1\%-5.8\%) and Liarla pardo (5.1\%-10.7\%) since 2018. The latter evidences where the channel's greatest potential resides. It manages to recover on weekends primetime with La Sexta noche (5.2\%-14.3\%) on Saturdays; and Salvados (7.5\%20.3\%) and El objetivo de Ana Pastor (5.3\%-12.5\%), on Sundays.

\section{Mediaset Analysis Results}

The last portion of the morning slot and the first of the Early afternoon slot, Monday to Friday, have been Telecinco's weaknesses for many seasons. As years 
went by, Telecinco lost audience at an alarming rate at the last hour of the morning slot. While in $2013 \mathrm{MyHyV}$ and De buena ley achieved values around 13\%; in 2017, MyHyV and Cámbiame fell to 9\%, following some modifications on the frame. In 2018, after moving $M y H y V$ to Cuatro and cancelling Cámbiame, Telecinco decided to premiere Ya es mediodía. This news program has gradually improved its time slot data, getting up to $13.2 \%$ mean weekly share (October 2019). Hence Telecinco seems to have found a functional format to compete in said frame.

Telecinco has also restructured its weekend's morning (last section) and Early afternoon (first section) slots. This was done by reducing reruns and betting on trademark content more aligned with its editorial strategy. Beginning with Cazamariposas (5.3\%-7.3\%), which did not quite take off and, since 2017, with Socialite (9.2\%-15.1\%). The latter has become a functional show that has allowed Telecinco to compensate for the loss of Grand prix motorcycle racing's broadcasting rights. On weekend afternoons it has also gambled on Qué tiempo tan feliz (11.8\%-13.7\%) and on channel's theme coherence with Viva la vida (9.3\%-10.9\%). The latter substituting, since 2017, the movies frame, as it did not compete well with Antena 3.

Another weakness of Telecinco is its access primetime. The other channels have stable night time formats, serving as access primetime, as is the case with $E l$ hormiguero (Antena 3), First dates (Cuatro) and El intermedio (La Sexta). Telecinco does not have a solid and recognizable access show that allows it to offer a more compact primetime to its viewers. The analysis also shows that reality and talent shows are, together with gossip, some of the best working genres for the channel, as is almost every edition of Gran Hermano (Table 2).

Table 2. Mean audience share of Telecinco's reality and talent shows

\begin{tabular}{l|l|l|l|l|l|l|l} 
Content & $\mathbf{2 0 1 3}$ & $\mathbf{2 0 1 4}$ & $\mathbf{2 0 1 5}$ & $\mathbf{2 0 1 6}$ & $\mathbf{2 0 1 7}$ & $\mathbf{2 0 1 8}$ & $\mathbf{2 0 1 9}$ \\
\hline $\begin{array}{l}\text { Mean yearly audience } \\
\text { Telecinco }\end{array}$ & $13.5 \%$ & $14.5 \%$ & $14.8 \%$ & $14.4 \%$ & $13.3 \%$ & $14.1 \%$ & $14.8 \%$ \\
\hline Gran hermano (GH) & & $21.4 \%$ & $23.1 \%$ & $19.6 \%$ & & & \\
\hline GH Revolution & & & & & $14.3 \%$ & & \\
\hline GH Vip & & & & & & $29.7 \%$ & $32.5 \%$ \\
\hline La voz & $23.1 \%$ & & & $24.1 \%$ & $17.8 \%$ & & \\
\hline La voz kids & & & $28.1 \%$ & & & & \\
\hline Got talent & & & & & & & $20.6 \%$ \\
\hline
\end{tabular}

Source: Authors. From Kantar media data provided by Barlovento Comunicación (Editions broadcast within the analysis period). 
As regards Cuatro the greatest weakness of this Mediaset channel has always been the Early afternoon and afternoon slot. Following the 2011 merger, Mediaset tried to raise the slot's ratings from Monday to Friday with No le digas a mamá que trabajo en la tele and the return of Allá tú, though both ended up failing. The network has tried different genres ever since, like Lo sabe no lo sabe (2\%$5 \%)$, Hazte un selfi (1.4\%-3.9\%), Dani\&Flo (3\%-4.2\%), Las tardes de Cuatro (not analyzed), Te vas a enterar (3\%-4\%) or Singles XD (not analyzed).

One of Mediaset's most controversial moves was to cancel Las mañanas de Cuatro from its morning slot in June 2018. It was Cuatro's most watched program at the time and the natural competitor of La Sexta's Al rojo vivo. The space presented by journalist Javier Ruiz often reached results above 15\% share since 2014. However, $\mathrm{MyHyV}$, currently working in tandem with El concurso del año (4.2\%-7.3\%), is barely exceeding $6 \%$ on its best days. This means an average fall of $50 \%$ in the morning slot compared to Las mañanas de Cuatro (9.3\%-15.1\%). Data confirm, on one hand, the political distancing Telecinco wants to impose on Cuatro, and on the other, the theme and style convergence between the two channels.

Cuatro also shows weaknesses in the primetime, with shows like ¿Quién quiere casarse con mi hijo? (7.7\%-9.6\%), Granjero busca esposa (7.7\%) or Hermano mayor (9.9\%-11.9\%), big gambles at the time, losing impulse throughout the seasons, some of them even getting cancelled. The best show in the last few months, entertainment-wise, has been Los gipsy kings. Nevertheless, it was left out of the study as it was broadcast on dates outside the analysis period. On occasion, Los gipsy kings have gotten $12 \%$ screen share on Friday nights, as was the case with $E l$ embarazo de la Rebe (I), broadcast on June 29, 2018, getting a $12.4 \%$ share.

\section{Four Analyzed Channels' Audience Evolution and Contribution of Programming To Brand Identity}

Telecinco is a network with stable results, though it depends on the success of its reality and/or talent shows. Thus, the failure of one such product, as what happened in 2017 with GH revolution (see Table 2), affects the entire network. Antena 3's descent data points to the need of new impulses. However, the rise of La Sexta can be found in parallel to Antena 3's fall, with the former rebounding every time there is a big news event, like in October 2017 and 2019. Spain's near-permanent upheaval in political and social life in the last years has played in favor of La Sexta's perspectives. Mediaset has still issues to resolve as Cuatro is the most unstable channel of the lot; it is loaded with doubts regarding its future.

Regarding the contribution of programming to creating brand identity (Q3), we can observe the alignments between both concepts in Table 3. 
Table 3. Contribution of programming to brand identity

\begin{tabular}{|c|c|c|c|}
\hline & $\begin{array}{l}\text { Brand identity } \\
\text { values* }\end{array}$ & $\begin{array}{l}\text { Contribution of programming (high, } \\
\text { medium, low) to brand identity }\end{array}$ & Examples \\
\hline \multirow{9}{*}{ 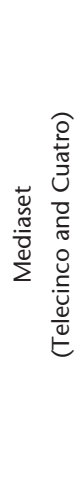 } & Information & Low & - \\
\hline & Entertainment & High & Talks, datings, talents... \\
\hline & Closeness & High & Live broadcasts (star format) \\
\hline & Immediacy & High & Live broadcasts (star format) \\
\hline & Company & High & Talk shows \\
\hline & Transversality & High & Transfers between channels \\
\hline & Leadership (share) & High & Realities \\
\hline & Own production & High & Fiction series \\
\hline & Variety of targets & High & Intergenerational programming \\
\hline \multirow{10}{*}{ 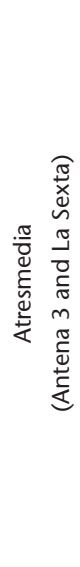 } & Information & High & La Sexta \\
\hline & Entertainment & High & Contests, talents... \\
\hline & Reflection & High & La Sexta \\
\hline & Emotion & Medium & - \\
\hline & Quality & High & Fiction series \\
\hline & Innovation & Medium & - \\
\hline & Plurality & High & Movies \\
\hline & Diversity & High & $\begin{array}{l}\text { Differentiated programming } \\
\text { Antena } 3 \text { / La Sexta }\end{array}$ \\
\hline & Credibility & High & TV news \\
\hline & Trust & High & Special coverages La Sexta \\
\hline
\end{tabular}

*Brand identity values taken from official reports of both TV groups.

\section{CONCLUSIONS}

The birth of Mediaset and Atresmedia has had very distinct effects on Cuatro and La Sexta's programming grids. However, both Cuatro and La Sexta have managed to stay afloat in a market where they would have had to go through serious economic viability issues. The integrations are to be thanked for that. It is noteworthy that, when comparing the evolution of audience and content of Antena 3, La Sexta, Telecinco and Cuatro, Telecinco shows the clearest, most stable programming strategy. Antena 3 has withdrawn from controversial and gossip contents (pillars of Telecinco). Likewise, it has largely abandoned the historically faulty strategy of trying to copy Telecinco's model.

In recent years it has focused on family entertainment, with shows targeted to all kinds of viewers. Cuatro's essence began to be diluted once the merger with 
Telecinco was fulfilled, when the former's contents became a copy of the latter's. The fear of Cuatro losing its beloved identity, turning it into a sort of shadow of Telecinco, has come to be realized. In contrast to Mediaset, Atresmedia has opted for a channel differentiation strategy.

In the case of Atresmedia, though some transfers occurred between Antena 3 and La Sexta after the fusion, these were less aggressive than those between Mediaset and Cuatro. From the beginning, Atresmedia respected the spirit and essence of each of its channels. It strengthened the pillars of each of them without "tainting" their contents. Moreover, it kept each channel's editorial line and programming model.

When verifying if programming creates brand identity (O.2 and Q.3), Telecinco is shown to base its programming model on the reality, talent, and gossip genres. Telecinco is the channel that best exploits these. Moreover, it has the ability to feedback certain contents into its other programs throughout the day, creating a sort of unique universe. Antena 3, on the other hand, has found really competitive contents in fiction (series and movies). La Sexta has inclined toward news, political debate, and entertainment with mixtures of humor and current events. Cuatro is living a moment of identity confusion, mixing its own shows like First dates and Callejeros, with elements imported from Telecinco. Still, its identity has dwindled and it has turned into a mere shadow of Telecinco.

When exploring and analyzing the evolution of the Spanish TV sector, especially since the double merger, Mediaset and Atresmedia's strategies become clearer. They have followed similar (they were both born from a union) and different (Mediaset re-thinks Cuatro, Atresmedia does not with La Sexta) paths. The sector transformation has been heavily influenced by the economic context (2007 crisis) and the regulatory framework (2010's LGCA). About Q.1, the contrast between Mediaset and Atresmedia can be highlighted. The former's efforts are completely focused on Telecinco's audience, whose programming model is very clear. It will have to figure out where Cuatro is heading to.

Atresmedia will have to continue looking for the key to Antena 3 getting closer to Telecinco's results. Respecting La Sexta's identity seems to be Atresmedia's best choice. This study shows (O.3) that the success of many programs in Spain depends more on its adequate placing in the grid, and on whatever the competition offers, rather than its intrinsic value. The placement, strategic, and economic values (Q.4) take precedence more than the intrinsic one (CortésLahera, 2001). Good results were seen in the last one for generalist contents with certain doses of culture and exciting or explosive endings.

Joaquín Sotelo-González (joaquin.sotelo@ ccinf.ucm.es) is a full-time professor at the Department of Journalism and New Media at the Faculty of Communication Studies at prestigious Complutense University of Madrid,
Spain. He has held a Spanish FPI Predoctoral Fellowship to finish his PhD in Journalism. He has enjoyed several research stays in the most prestigious international universities, such as Oxford University in England or the European 
University Institute in Florence, Italy. He has been part of more than ten research groups in the field of Communication and has received several mentions of teaching excellence. He

Javier Sierra-Sánchez (javier_sierra@ucm.es) holds a PhD in Communication Studies from the Complutense University of Madrid, where he is also a full-time lecturer and researcher. He is also responsible for the Mass Media Relations Cabinet in the Government Team at this prestigious university. He obtained a Master in Marketing and Corporate Communication

Francisco Cabezuelo-Lorenzo (fcabezuelo@ ucm.es) is a full-time lecturer and researcher at the Department of Journalism and Global Communication at the prestigious Complutense University of Madrid, Spain, where he obtained his PhD, MA and BA in Journalism Studies. He also holds a PhD in Audiovisual Communication and Advertising from Abat Oliba CEU University in Barcelona. He is the author responsible for more than 65 papers in has been recognized as a researcher with two "research periods" (sexenios) and another "Knowledge and Transfer period" by the Spanish National Agency CNEAI-ANECA.

from San Jorge University, Zaragoza, Spain. He is also an expert in Protocole, Event Management and Public Relations. He has a large academic career with experience in several public and private universities in Madrid, Barcelona and Zaragoza. He is one of the most relevant authors in Communication Studies in Spanish according to Google Scholar.

academic journals, a hundred of book chapters and several compilations and books. He was a large international experience abroad with long time periods in the USA, Canada and UK. Under the Erasmus umbrella, he is a frequent visiting lecturer in several EU countries such as Italy, Portugal, Poland, Germany, Lithuania or The Netherlands. He is a prominent author in the field of Communication Studies in Spanish according to his Google Academic index.

\section{References}

Albújar, Marta (2018). La transformación de la industria de la televisión en España: Transición tecnológica, regulación digital y redefinición de los mercados audiovisuales (2010-2016). PhD Thesis. Autonomous University of Barcelona. Available at: <https://www.tdx.cat/ handle/10803/666766\#page $=1>$. Accessed 14 June 2019.

Arana, Edorta (2011). Estrategias de programación televisiva. Madrid: Síntesis.

Artero-Muñoz, Juan P. (2007). Modelos estratégicos de Telecinco (1990-2005). Madrid: Fragua.
Barlovento Comunicación (2006). Análisis televisivo anual 2006. Available at: <https://www.barloventocomunicacion. es/wp-content/uploads/2018/12/2006AN\%C3\%81LISIS-TELEVISIVO.pdf $>$. Accessed 12 May 2019.

-. (2012). "Análisis televisivo anual 2012". Available at: <https://www.barloventocomunicacion.es/audiencias-anuales/analisistelevisivo-2012/>. Accessed 12 May 2019.

-. (2013). “Análisis televisivo anual 2013". Available at: <https://www.barloventocomunicacion.es/audiencias-anuales/analisistelevisivoi-2013/>. Accessed 12 May 2019. 
-. (2014). "Análisis televisivo anual 2014". Availableat:<https://www.barlovento comunicacion.es/audiencias-anuales/ analisis-televisivo-2014-2/>. Accessed 12 May 2019.

-. (2019). "Análisis televisivo 2019". Available at: <https://www.barlovento com un i ca cion.es/wp - content/ uploads/2019/12/analisis-televisivo-2019BarloventoComunicacion-1.pdf Accessed 12 May 2019>. Accessed 12 May 2019.

Berelson, Bernard (1952). Content Analysis in Communication Research. Glencoe: The Free Press.

Bustamante, Enrique (2013). Historia de la radio y la televisión en España. Una asignatura pendiente de la democracia. Madrid: Gedisa.

Cabezuelo, Francisco (2013). "Cinco años de crisis en el mercado de la comunicación (2008-2013)". Historia y Comunicación Social, 18 (Special December 2013), pp. 703-715.

Cavaller, Víctor; Vila, Alícia, and Roca, Mercè (2013). Análisis de audiencias y estrategias de visibilidad. Barcelona: UOC.

Contreras, José M. and Palacio, Manuel (2001). La programación de televisión. Madrid: Síntesis.

Cortés-Lahera, José Á. (2001). La estrategia de la seducción. La programación en la neotelevisión. Pamplona: Eunsa.

Cubells, Mariola (2003). ¡Mírame tonto!: Las mentiras impunes de la tele. Barcelona: Marsterclass.

Cuilenburg, Jan van (2000). "On Measuring Media Competition and Media Diversity: Concepts, Theories and Methods". In: Picard, Robert (ed.). Measuring Media Content, Quality, and Diversity. Finland: Turku School of Economics and Business Administration, pp. 51-80.

Fernández-Navarrete, Donato (2016). "La crisis económica española: Una gran operación especulativa con graves consecuencias". Estudios internacionales. Revista del Instituto de Estudios Internacionales de la Universidad de Chile, 48 (183), pp. 119-151.
Ferrer, Rosa M. (2016). Calidad televisiva y "mala" televisión. Los programas contenedores en los canales de televisión españoles. PhD Thesis Doctoral. Autonomous University of Barcelona. Available at: <https://www.tdx.cat/ bitstream/handle/10803/399452/rmfc1de1. pdf? sequence $=1 \&$ isAllowed $=y>$. Accessed 10 June 2019.

Galindo, Fernando (2004). Comunicación audiovisual corporativa. Cómo audiovisualizar la identidad de las organizaciones. Salamanca: Publicaciones Universidad Pontificia de Salamanca.

Gómez-Pérez, Francisco J.; Navarrete, José L., and Pérez-Rufí, José P. (2013). “La industria televisiva en España: Crisis y nuevas oportunidades". Anàlisi. Quaderns de Comunicació i Cultura, 49, pp. 1-14.

González-Oñate, Cristina (2008). Nuevas estrategias de televisión. El desafío digital. Identidad, marca y continuidad televisiva. Madrid: Ediciones Ciencias Sociales.

Guerrero, Enrique (2005): "El concurso como género de calidad en la televisión española". Comunicar. Revista Científica Iberoamericana de Comunicación y Educación, 25 (2).

InfoAdex (2012). "Estudio InfoAdex de la Inversión Publicitaria en España 2012". Available at: <https://www.infoadex.es/home/ wp-content/uploads/2017/12/RESUMEN2012.pdf> Accessed 20 March 2019.

-. (2020). "Estudio InfoAdex de la Inversión Publicitaria en España 2020". Available at: $\quad<$ https://www.infoadex.es/home/wpcontent/uploads/2020/02/NP-Estudio-Info Adex-de-la-Inversi\%C3\%B3n-Publicitariaen-Espa\%C3\%B1a-2020.pdf>. Accessed 20 March 2019.

Íñigo, José M. (2013). La tele que fuimos: Del 'Un, dos, tres' a la telebasura. Barcelona: Ediciones B.

Izquierdo-Castillo, Jéssica (2016). Teoría de programación de radio y televisión. Castelló de la Plana: Publicacions de la Universitat Jaume I. 
Krippendorff, Klaus (1990). Metodología del análisis de contenido. Teoría y Práctica. Barcelona: Paidós.

Lijphart, Arend (1971). "Comparative Politics and the Comparative Method". The American Political Science Review, 65 (3), pp. 682-693.

Losada, José C. (2002). Prensa e imagen corporativa en la universidad. Murcia: Quaderna Editorial.

Martín, Enrique (1963). "El análisis de contenido". Revista de Estudios Políticos, 132, pp. 45-64.

Marzal-Felici, Javier (2007). El desarrollo de la televisión digital en España. A Coruña: Netbiblo.

Mediaset España (2018). "Informe anual corporativo 2018". Available at: <https://files. mediaset.es/file/10002/2019/04/25/informe_ anual_corporativo_2018_cebe.pdf> Accessed 3 May 2019.

Medina-Laverón, Mercedes (2006). Calidad y contenidos audiovisuales. Pamplona: Ediciones Universidad de Navarra.

-. (2015). Estructura y gestión de las empresas audiovisuales. Pamplona: Eunsa.

Melgarejo, Irene and Rodríguez-Rosell, María M. (2012). "La creación de imagen de marca en los canales infantiles politemáticos de televisión". Miguel Hernández Communication Journal, 3, pp. 37-55.

Mora-Figueroa, Borja (2009). El mercado global de la comunicación. Éxitos y fracasos. Navarra: Eunsa.

Pedrero, Luis M. (2008). "Armas de seducción catódica. Los géneros de entretenimiento en la neotelevisión contemporánea". In: Sangro, Pedro; Salgado, Alejandro. El entretenimiento en TV: Guión y creación de formatos de humor en España. Barcelona: Alertes, pp. 33-53.

Pérez-Tornero, José M. (2005). "Los ciudadanos y la televisión. Participación, regulación y asociacionismo en Europa". Anàlisi. Quaderns de Comunicació i Cultura, 32, pp. 251-256.
Polo, Marcos (2017). La planificación de medios y la fragmentación de audiencias. Incidencia de la televisión a la carta en la evolución del Prime Time en España. PhD Thesis. Ramon Llull University, Spain.

Pujadas, Eva and Oliva, Mercè (2007). "La evaluación de la diversidad de la programación televisiva." Quaderns del CAC, 28, pp. 85-97.

Rodríguez, Gregorio; Gil, Javier, and García, Eduardo (1996). Metodología de la investigación cualitativa. Málaga: Aljibe.

Sartori, Giovanni (1984). La política, lógica y método en las ciencias sociales. Mexico: Fondo de Cultura Económico.

Sotelo-González, Joaquín (2017a). “El negocio de la televisión en España: Cosa de dos". In: Martínez-Valero, Lizette (coord.). Cultura popular y medios audiovisuales en la historia contemporánea. Madrid: Complutense University of Madrid, pp. 141-169.

—. (2017b). "TVE 2012-2016: Quinquenio negro". In: Valle-Rojas, Carlos del and Salgado-Santamaría, Carmen (coords.). Nuevas formas de expresión en comunicación. Madrid: McGraw-Hill/Interamericana de España, pp. 721-737.

Soto, Laura (2005). "Televisión rosa. Amarillismo y telebasura". Revista Latinoamericana de Comunicación Chasqui, 90, pp. 52-58.

Vaca-Berdayes, Ricardo (2009). El puzle de la audiencia televisiva. Madrid: Fundación Ex-Libris.

Villagrasa, José M. (2011). ¡Atrápalos como puedas! La competencia televisiva: Programación y géneros. Valencia: Tirant lo Blanch.

Zubiaurre, Luis de (2009): "La fragmentación de las audiencias". In: Francés-Doménec, Miquel (coord.). Hacia un nuevo modelo televisivo. Contenidos para la Televisión Digital. Barcelona: Gedisa, pp. 263-271.

Zunzunegui, Santos (2003). Pensar la imagen. Madrid: Cátedra. 
APPENDIX

COMPARISON OF PROGRAMMING GRIDS BETWEEN THE FOUR CHANNELS STUDIED 2013-2019)

Week from October 14 to 20, 2013

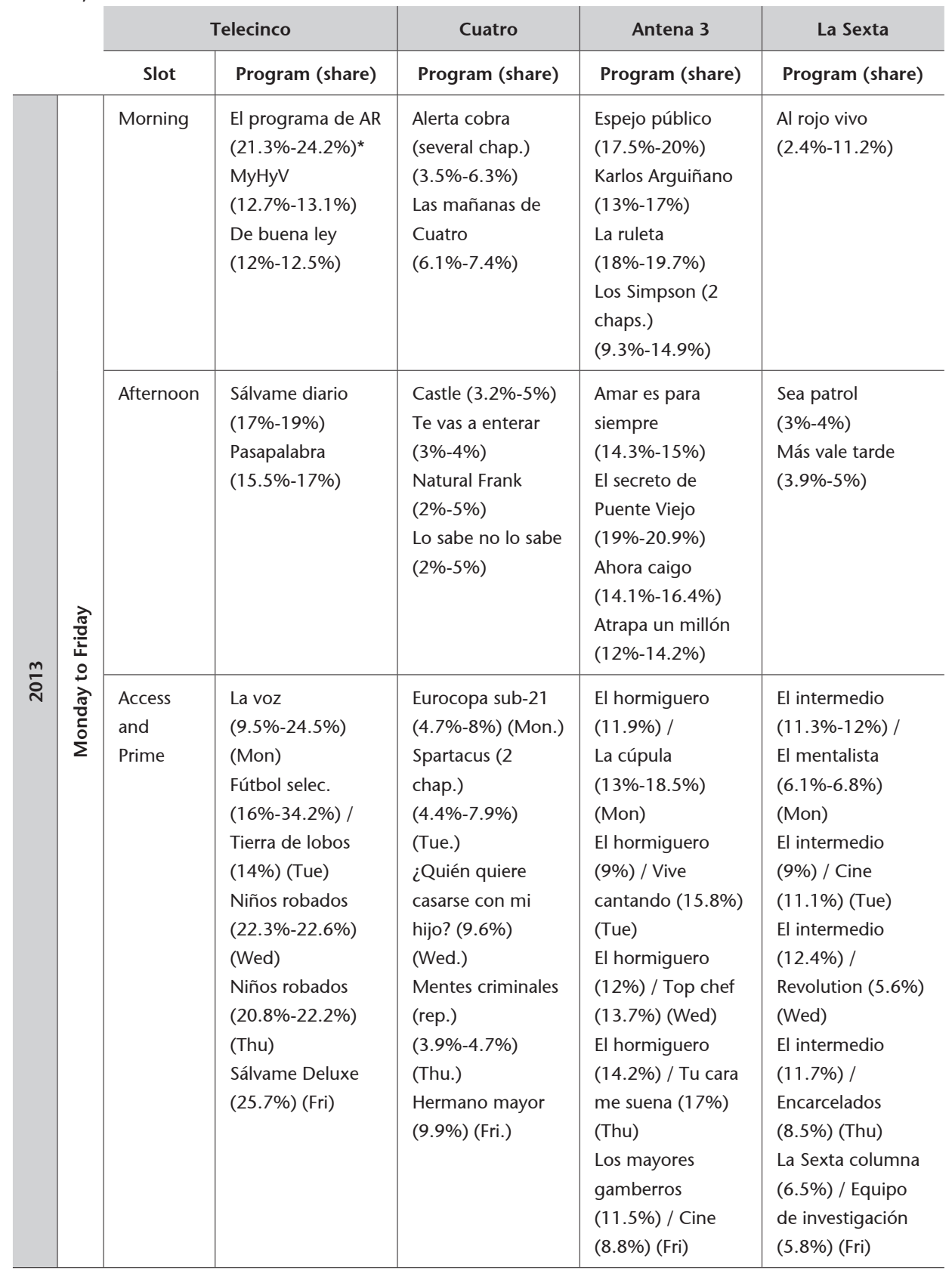




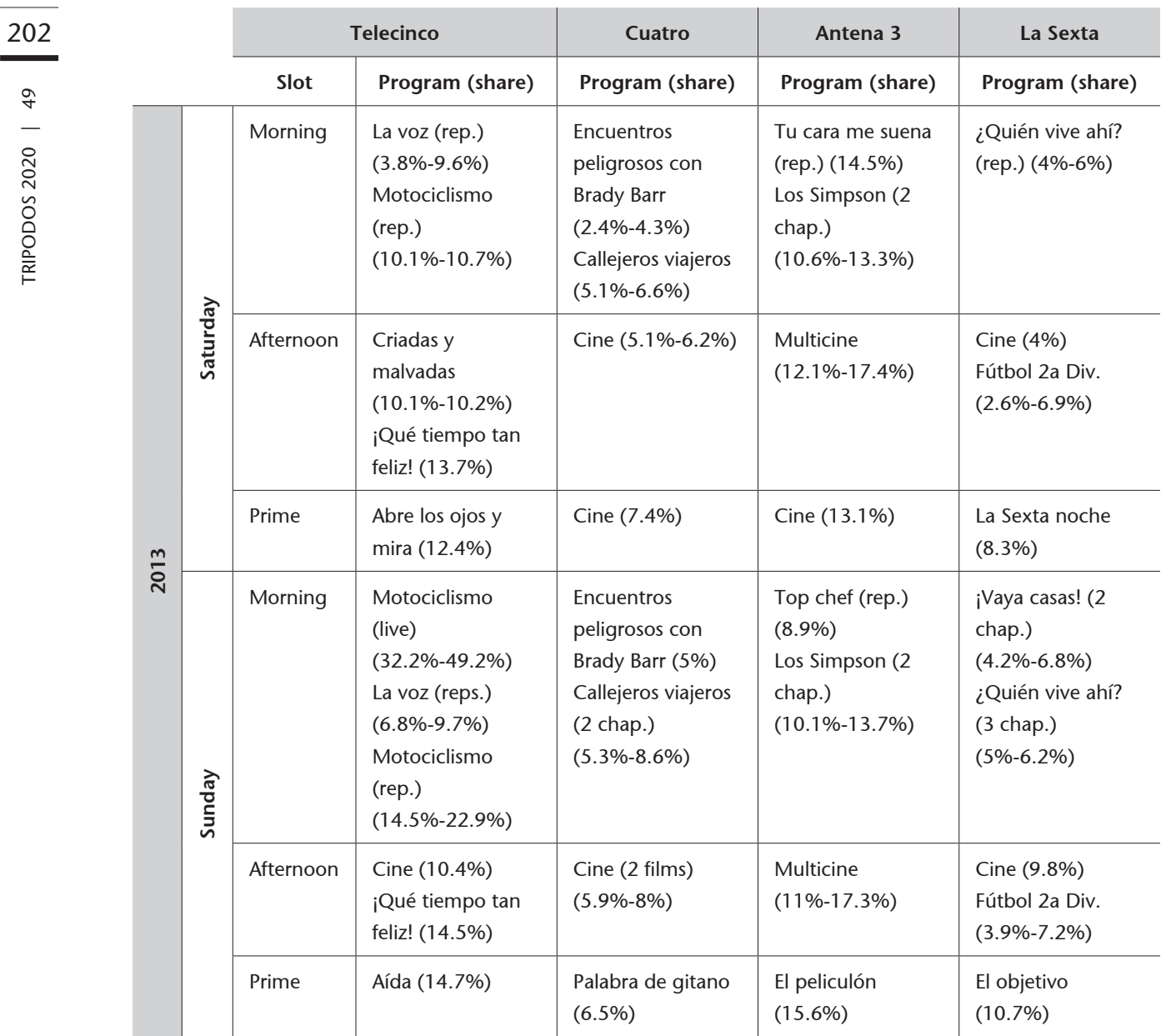

* The lowest and highest audience share is given (in parenthesis) where available (whether on its day of broadcast or overall in the week). The mean audience share is given where not available. 
Week from October 13 to 19, 2014

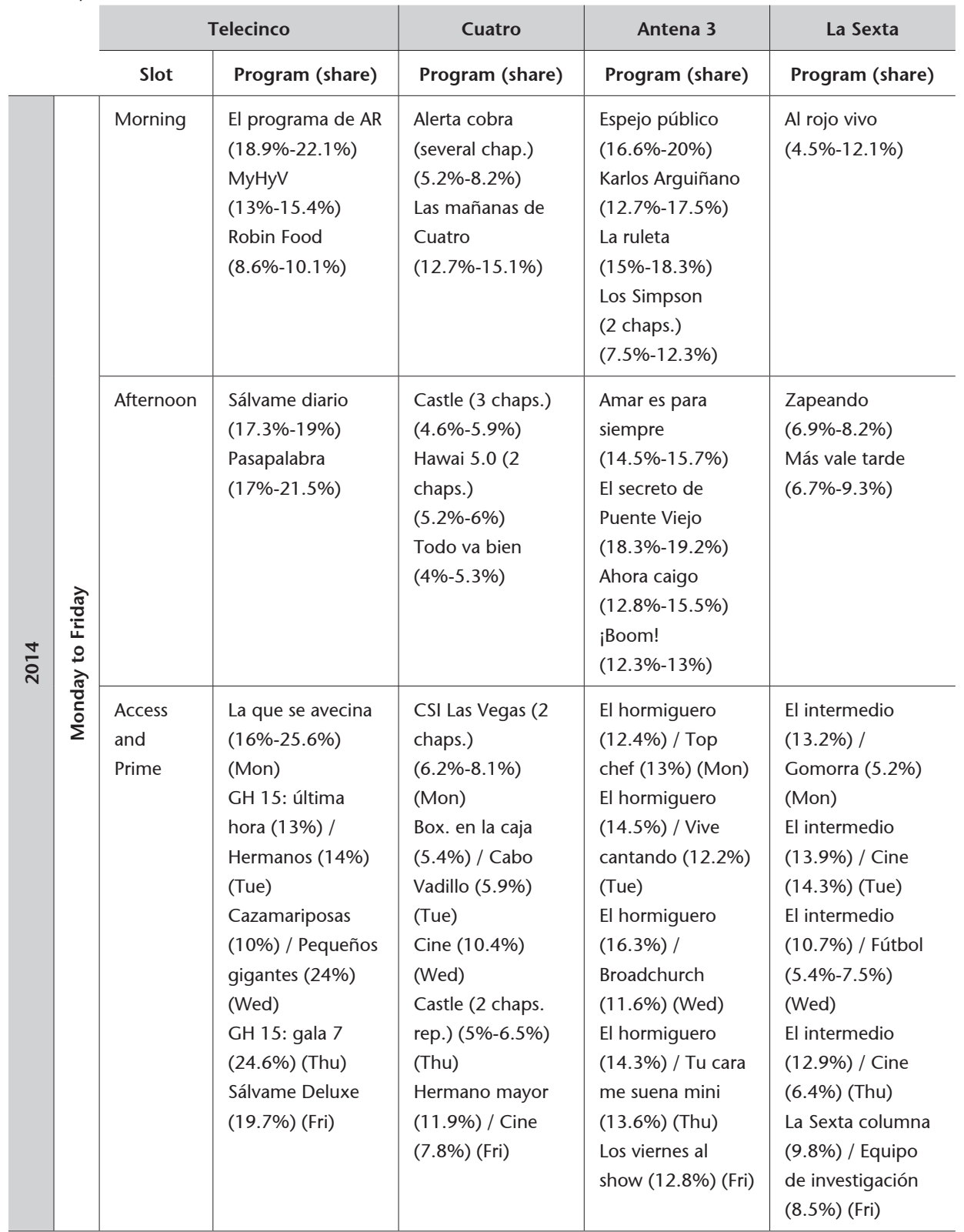




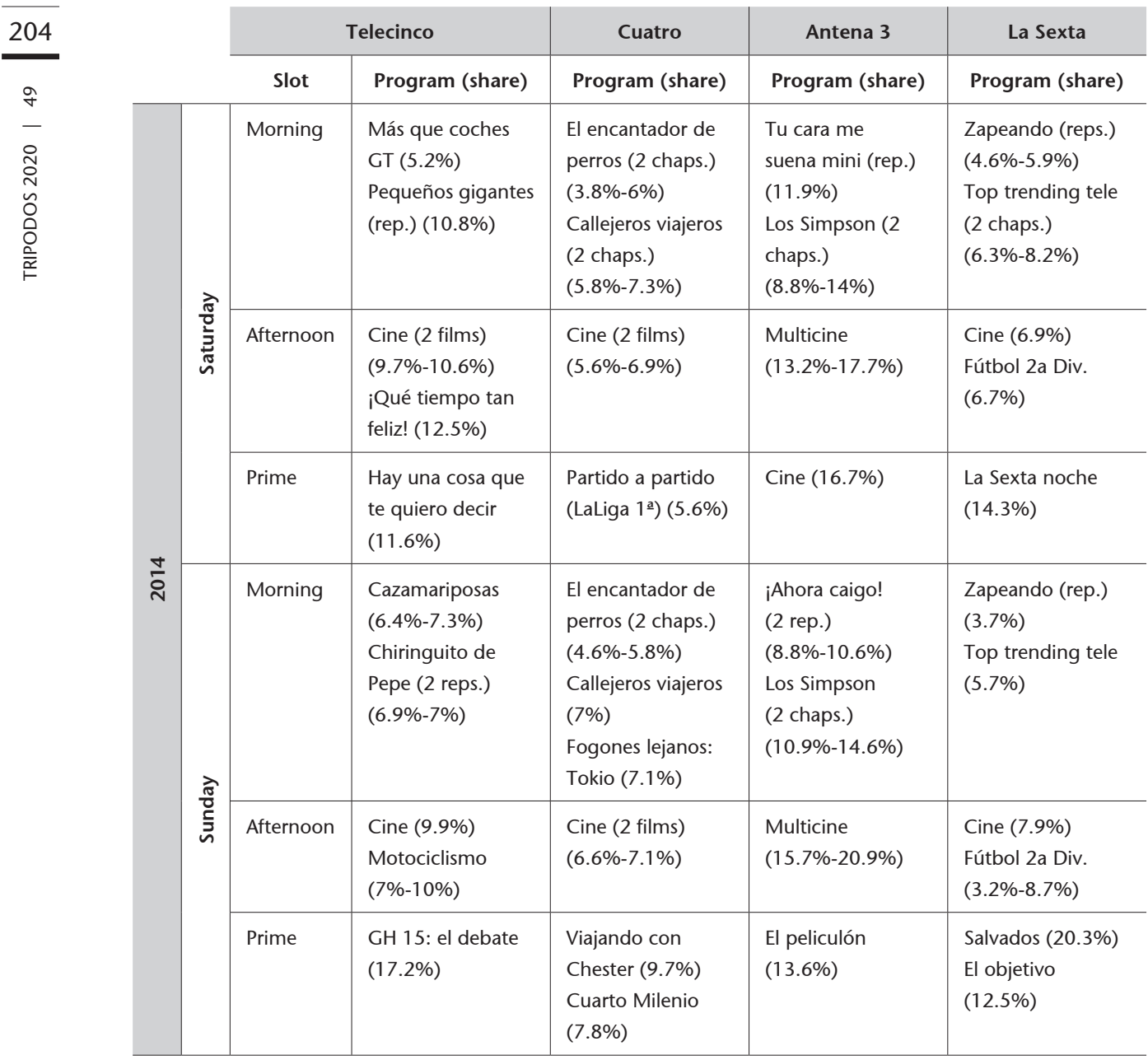


Week from October 19 to 25, 2015

\begin{tabular}{|c|c|c|c|c|c|c|}
\hline \multicolumn{4}{|c|}{ Tele } & \multirow{2}{*}{$\begin{array}{c}\text { Cuatro } \\
\text { Program (share) }\end{array}$} & \multirow{2}{*}{$\begin{array}{c}\text { Antena } 3 \\
\text { Program (share) }\end{array}$} & \multirow{2}{*}{$\begin{array}{c}\text { La Sexta } \\
\text { Program (share) }\end{array}$} \\
\hline & & Slot & Program (share) & & & \\
\hline \multirow{3}{*}{$\frac{n}{i}$} & \multirow{3}{*}{ 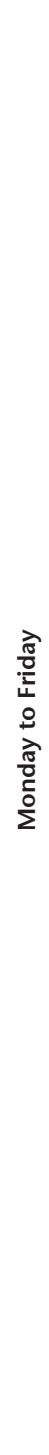 } & Morning & $\begin{array}{l}\text { El programa de AR } \\
(19.3 \%-20.6 \%) \\
\text { MyHyV } \\
(13 \%-15.5 \%) \\
\text { Cámbiame } \\
(12.8 \%-14.2 \%)\end{array}$ & $\begin{array}{l}\text { Alerta cobra } \\
\text { (several chaps.) } \\
(5.6 \%-8.7 \%) \\
\text { Las mañanas de } \\
\text { Cuatro } \\
(10.9 \%-11.8 \%)\end{array}$ & $\begin{array}{l}\text { Espejo público } \\
(16.8 \%-19.1 \%) \\
\text { Karlos Arguiñano } \\
(13 \%-18.5 \%) \\
\text { La ruleta } \\
\text { (15\%-18\%) } \\
\text { Los Simpson (2 } \\
\text { chaps.) } \\
\text { (7.6\%-13.2\%) }\end{array}$ & $\begin{array}{l}\text { Al rojo vivo } \\
(10 \%-13.4 \%)\end{array}$ \\
\hline & & Afternoon & $\begin{array}{l}\text { Sálvame diario } \\
\text { (limón / naranja) } \\
(13.6 \%-19.5 \%) \\
\text { Pasapalabra } \\
(17 \%-18.4 \%)\end{array}$ & $\begin{array}{l}\text { Hawai } 5.0 \text { (varios } \\
\text { chaps.) } \\
(4.9 \%-6.9 \%) \\
\text { Las reglas del } \\
\text { juego } \\
(5.6 \%-6.8 \%)\end{array}$ & $\begin{array}{l}\text { Amar es para } \\
\text { siempre } \\
(13.8 \%-14.8 \%) \\
\text { El secreto de } \\
\text { Puente Viejo } \\
(17.8 \%-18.9 \%) \\
\text { Ahora caigo } \\
(14.6 \%-16.2 \%) \\
\text { ¡Boom! } \\
(12 \%-14.2 \%)\end{array}$ & $\begin{array}{l}\text { Zapeando } \\
(6.4 \%-7.7 \%) \\
\text { Más vale tarde } \\
(5.4 \%-6.7 \%)\end{array}$ \\
\hline & & $\begin{array}{l}\text { Access } \\
\text { and } \\
\text { Prime }\end{array}$ & $\begin{array}{l}\text { La voz kids } \\
\text { (17.8\%-27.6\%) } \\
\text { (Mon) } \\
\text { GH: límite } 48 \\
\text { horas (16\%) (Tue) } \\
\text { Cámbiame de } \\
\text { noche (9.5\%) / } \\
\text { B\&B de boca en } \\
\text { boca (13.1\%) } \\
\text { (Wed) } \\
\text { GH 16: express / } \\
\text { gala } 7 \\
\text { (14.1\%-20.8\%) } \\
\text { (Thu) } \\
\text { Sálvame Deluxe } \\
\text { (13.5\%-20.4\%) } \\
\text { (Fri) }\end{array}$ & $\begin{array}{l}\text { Gym Tony (4.7\%) } \\
\text { / Rabia (5.5\%) } \\
\text { (Mon) } \\
\text { Gym Tony (5\%) / } \\
\text { CSI Cyber (6.3\%) } \\
\text { (Tue) } \\
\text { Gym Tony (5.7\%) } \\
\text { / Adán y Eva } \\
\text { (8.2 \%) (Wed) } \\
\text { Gym Tony (5\%) / } \\
\text { Mentes criminales } \\
\text { (7.9\%) (Thu) } \\
\text { Gym Tony (5.7\%) } \\
\text { / Cine (10.1\%) } \\
\text { (Fri) }\end{array}$ & $\begin{array}{l}\text { El hormiguero } \\
(15.9 \%) / \\
\text { Redención } \\
(14.4 \%) \text { (Mon) } \\
\text { El hormiguero } \\
\text { (14.4\%)/ Mar de } \\
\text { plástico (21.5\%) } \\
\text { (Tue) } \\
\text { El hormiguero } \\
\text { (12.9\%) / Top } \\
\text { chef (12.5\%) } \\
\text { (Wed) } \\
\text { El hormiguero } \\
\text { (14.5\%) / Velvet } \\
\text { (17.3\%) (Thu) } \\
\text { Tu cara me suena } \\
\text { (11.8\%-20.1\%) } \\
\text { (Fri) }\end{array}$ & $\begin{array}{l}\text { El intermedio } \\
(12 \%) / \text { Cine } \\
(7.3 \%) \text { (Mon) } \\
\text { El intermedio } \\
(12 \%) / \text { El jefe } \\
\text { infiltrado (9.8\%) } \\
\text { (Tue) } \\
\text { El intermedio } \\
(12.8 \%) / \text { Cine } \\
\text { (8.6\%) (Wed) } \\
\text { El intermedio } \\
\text { (12.2\%) / Cine } \\
\text { (9.1\%) (Thu) } \\
\text { La Sexta columna } \\
\text { (6.3\%-8.7\%) } \\
\text { / Equipo de } \\
\text { investigación } \\
\text { (5.6\%) (Fri) }\end{array}$ \\
\hline
\end{tabular}




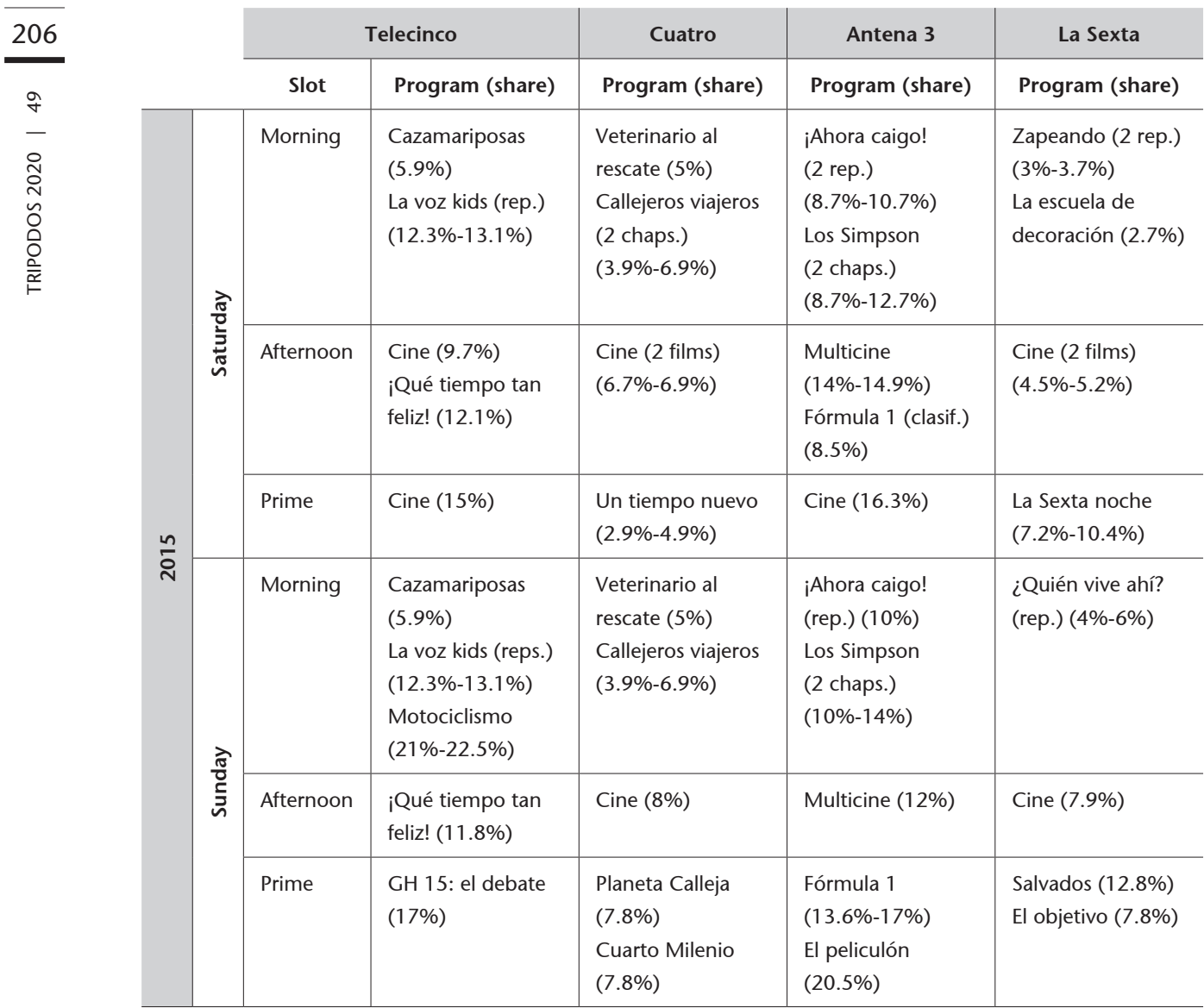


Week from October 17 to 23, 2016

\begin{tabular}{|c|c|c|c|c|c|c|}
\hline \multicolumn{4}{|c|}{ Tel } & \multirow{2}{*}{$\begin{array}{c}\text { Cuatro } \\
\text { Program (share) }\end{array}$} & \multirow{2}{*}{$\begin{array}{c}\text { Antena } 3 \\
\text { Program (share) }\end{array}$} & \multirow{2}{*}{$\begin{array}{c}\text { La Sexta } \\
\text { Program (share) }\end{array}$} \\
\hline & & Slot & Program (share) & & & \\
\hline \multirow{3}{*}{$\frac{0}{i}$} & \multirow{3}{*}{ 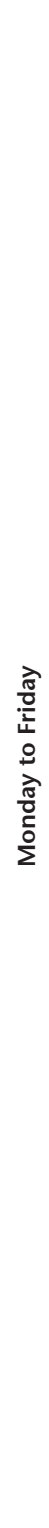 } & Morning & $\begin{array}{l}\text { El programa de AR } \\
(18.8 \%-21.8 \%) \\
\text { MyHyV } \\
(11.1 \%-13.5 \%) \\
\text { Cámbiame } \\
(12 \%-13.7 \%)\end{array}$ & $\begin{array}{l}\text { Alerta cobra } \\
\text { (several chaps.) } \\
(4.2 \%-8.7 \%) \\
\text { Las mañanas de } \\
\text { Cuatro } \\
(7 \%-12.3 \%)\end{array}$ & $\begin{array}{l}\text { Espejo público } \\
(10.9 \%-21.9 \%) \\
\text { Karlos Arguiñano } \\
(13 \%-17.3 \%) \\
\text { La ruleta } \\
(15 \%-17.9 \%) \\
\text { Los Simpson } \\
\text { (2 chaps.) } \\
(7.2 \%-12.4 \%)\end{array}$ & $\begin{array}{l}\text { Al rojo vivo } \\
(5.1 \%-14.2 \%)\end{array}$ \\
\hline & & Afternoon & $\begin{array}{l}\text { Sálvame diario } \\
\text { (limón/naranja) } \\
(12 \%-19.3 \%) \\
\text { Pasapalabra } \\
(15.3 \%-18.3 \%)\end{array}$ & $\begin{array}{l}\text { Hazte un selfi } \\
(1.4 \%-3.9 \%) \\
\text { Hawai } 5.0 \\
\text { ( } 2 \text { chaps.) } \\
(3.1 \%-6 \%) \\
\text { Ncis Los Ángeles } \\
(3.6 \%-5 \%)\end{array}$ & $\begin{array}{l}\text { Amar es para } \\
\text { siempre } \\
(11.8 \%-13.5 \%) \\
\text { El secreto de } \\
\text { Puente Viejo } \\
(16.6 \%-17.5 \%) \\
\text { Ahora caigo } \\
(14 \%-15.3 \%) \\
\text { ¡Boom! } \\
(10.7 \%-11.9 \%)\end{array}$ & $\begin{array}{l}\text { Zapeando } \\
(6.9 \%-8.1 \%) \\
\text { Más vale tarde } \\
(5.8 \%-9 \%)\end{array}$ \\
\hline & & $\begin{array}{l}\text { Access } \\
\text { and } \\
\text { Prime }\end{array}$ & $\begin{array}{l}\text { La que se avecina } \\
(8.4 \%-21.4 \%) \\
\text { (Mon) } \\
\text { GH: límite } 48 \\
\text { horas } \\
(9.2 \%-16.5 \%) \\
\text { (Tue) } \\
\text { La voz } \\
\text { (15\%-25.5\%) } \\
\text { (Wed) } \\
\text { GH: gala } \\
\text { (12.6\%-19.3\%) } \\
\text { (Thu) } \\
\text { Sálvame Deluxe } \\
\text { (11.4\%-16.3\%) } \\
\text { (Fri) }\end{array}$ & $\begin{array}{l}\text { First dates } \\
(10.6 \%) / \text { Cine } \\
(6.9 \%) \text { (Mon) } \\
\text { First dates } \\
(3.1 \%-8 \%) / \\
\text { Granjero busca } \\
\text { esposa (7.7\%) } \\
\text { (Tue) } \\
\text { First dates (8.2\%) } \\
\text { / Cine (6.7\%) } \\
\text { (Wed) } \\
\text { First dates } \\
\text { (5.7\%-9.4\%) / CSI } \\
\text { (4.7\%) (Thu) } \\
\text { First dates (8\%) / } \\
\text { Cine (9.7\%) (Fri) }\end{array}$ & $\begin{array}{l}\text { El hormiguero } \\
(15.7 \%) / \text { Mar de } \\
\text { plástico (17.6\%) } \\
\text { (Mon) } \\
\text { Fútbol Champions } \\
\text { (31.1\%) (Tue) } \\
\text { El hormiguero } \\
\text { (13.4\%) / Velvet } \\
(20.1 \%) \text { (Wed) } \\
\text { El hormiguero } \\
\text { (14.3\%) / Cine } \\
\text { (11.6\%) (Thu) } \\
\text { Tu cara me suena } \\
\text { (12.5\%-23.2\%) } \\
\text { (Fri) }\end{array}$ & $\begin{array}{l}\text { El intermedio } \\
(10 \%) \text { / Cine } \\
(6.2 \%) \text { (Mon) } \\
\text { El intermedio } \\
(10 \%) \text { / Enviado } \\
\text { especial (10.9\%) / } \\
\text { El objetivo (6.7\%) } \\
\text { (Tue) } \\
\text { El intermedio } \\
\text { (9.7\%) / Cine } \\
\text { (5\%) (Wed) } \\
\text { El intermedio } \\
\text { (10.8\%) / } \\
\text { Pesadilla en la } \\
\text { cocina (11.8\%) } \\
\text { (Thu) } \\
\text { La Sexta columna } \\
\text { (8.4\%) / Equipo } \\
\text { de investigación } \\
\text { (6.6\%) (Fri) }\end{array}$ \\
\hline
\end{tabular}




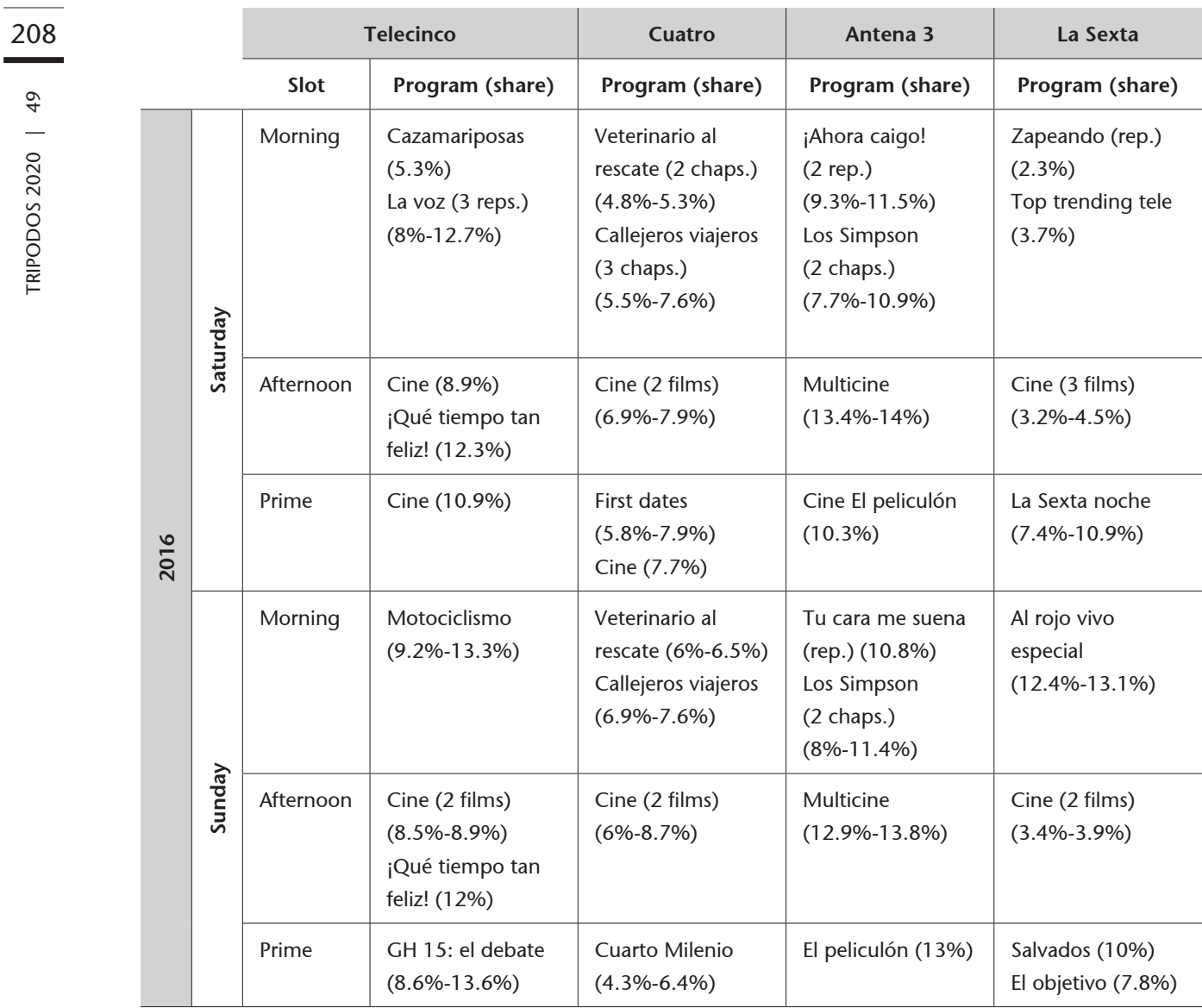


Week from October 16 to 22, 2017 (Catalonia's 1-O referendum month)

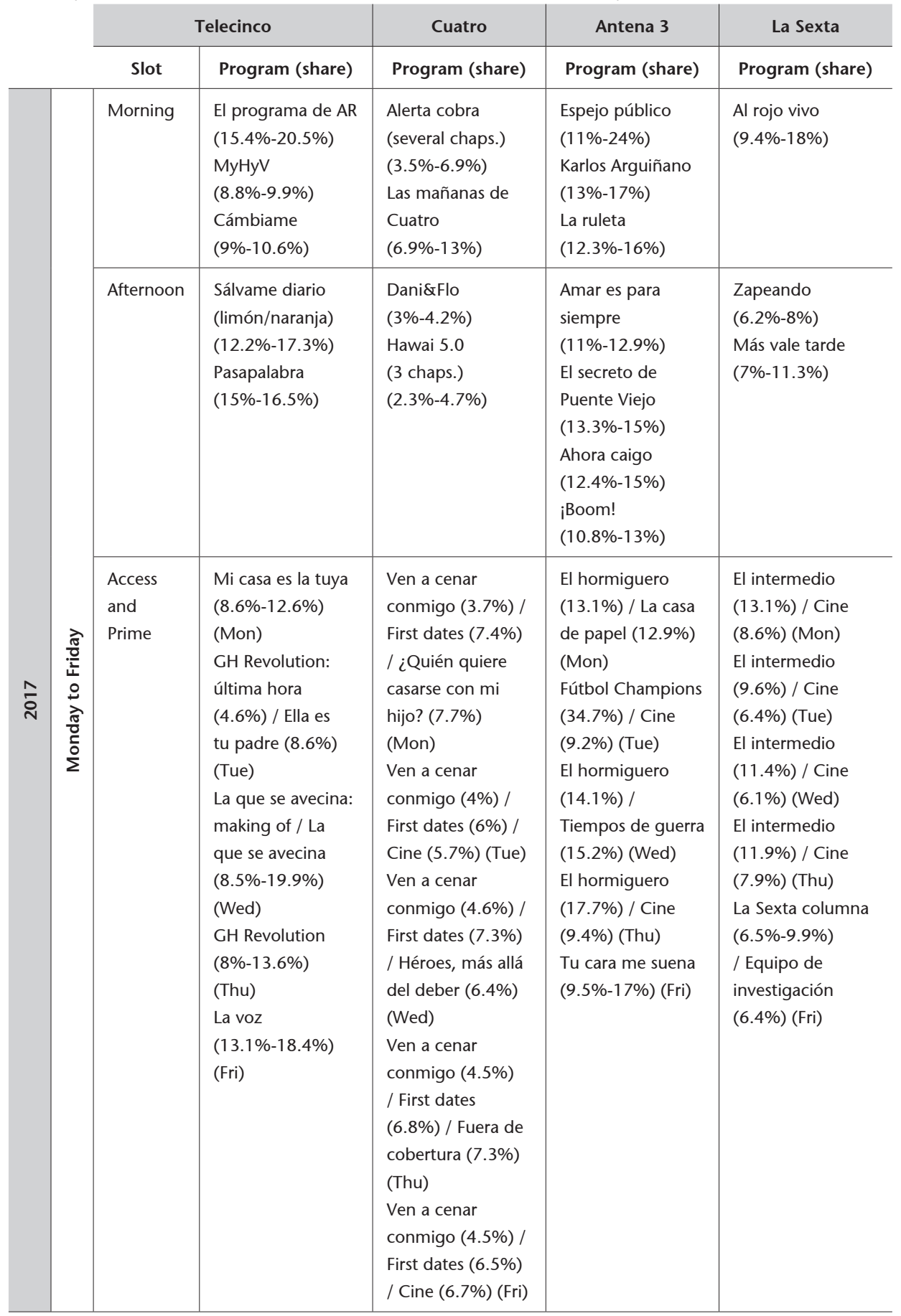




\begin{tabular}{|c|c|c|c|c|c|c|c|}
\hline \multirow{3}{*}{ 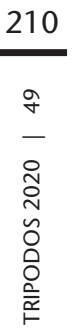 } & & & \multicolumn{2}{|c|}{ Telecinco } & \multirow{2}{*}{$\begin{array}{c}\text { Cuatro } \\
\text { Program (share) }\end{array}$} & \multirow{2}{*}{$\begin{array}{c}\text { Antena } 3 \\
\text { Program (share) }\end{array}$} & \multirow{2}{*}{$\begin{array}{c}\text { La Sexta } \\
\text { Program (share) }\end{array}$} \\
\hline & & & Slot & Program (share) & & & \\
\hline & \multirow{6}{*}{$\bar{i}$} & \multirow{3}{*}{ 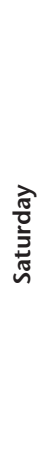 } & Morning & $\begin{array}{l}\text { Más que coches } \\
(4.8 \%) \\
\text { El programa de AR } \\
\text { especial Cataluña } \\
(10.1 \%)\end{array}$ & $\begin{array}{l}\text { El encantador de } \\
\text { perros }(4.1 \%) \\
\text { Callejeros viajeros } \\
\text { ( } 3 \text { chaps.) } \\
(4.7 \%-6.2 \%)\end{array}$ & $\begin{array}{l}\text { Antena } 3 \text { Noticias } \\
\text { especial Cataluña } \\
(7.8 \%)\end{array}$ & $\begin{array}{l}\text { Al rojo vivo } \\
\text { especial Cataluña } \\
(12.8 \%-17.9 \%)\end{array}$ \\
\hline & & & Afternoon & $\begin{array}{l}\text { Cine }(11.2 \%) \\
\text { Viva la vida } \\
(10.9 \%)\end{array}$ & $\begin{array}{l}\text { Cine (2 films) } \\
(4.4 \%-8.2 \%)\end{array}$ & $\begin{array}{l}\text { Multicine } \\
\text { (11.5\%-14.9\%) }\end{array}$ & Cine (6.6\%) \\
\hline & & & Prime & $\begin{array}{l}\text { Sábado deluxe } \\
(12.5 \%)\end{array}$ & $\begin{array}{l}\text { First dates }(4.6 \%) \\
\text { / Cine }(9.6 \%)\end{array}$ & $\begin{array}{l}\text { Cine El peliculón } \\
(11.2 \%)\end{array}$ & $\begin{array}{l}\text { La Sexta noche } \\
(11.7 \%)\end{array}$ \\
\hline & & \multirow{3}{*}{ 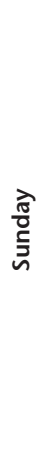 } & Morning & $\begin{array}{l}\text { La voz (rep.) } \\
(6.8 \%-11 \%) \\
\text { Socialité by } \\
\text { Cazamariposas } \\
(9.2 \%)\end{array}$ & $\begin{array}{l}\text { El encantador de } \\
\text { perros }(5 \%) \\
\text { Callejeros viajeros } \\
\text { ( } 3 \text { chaps.) } \\
(7.3 \%-7.7 \%)\end{array}$ & $\begin{array}{l}\text { Tu cara me suena } \\
\text { (rep.) }(9.1 \%) \\
\text { Los Simpson } \\
\text { ( } 2 \text { chaps.) } \\
(6.9 \%-9.6 \%)\end{array}$ & $\begin{array}{l}\text { Zapeando (reps.) } \\
(4.4 \%-5.9 \%) \\
\text { Top trending tele } \\
(3 \%)\end{array}$ \\
\hline & & & Afternoon & $\begin{array}{l}\text { Cine }(8.1 \%) \text { / Viva } \\
\text { la vida }(9.3 \%)\end{array}$ & $\begin{array}{l}\text { Cine (2 films) } \\
(5.8 \%-6.8 \%)\end{array}$ & $\begin{array}{l}\text { Multicine } \\
(10.7 \%-14.7 \%)\end{array}$ & $\begin{array}{l}\text { Cine (3 films) } \\
(3.5 \%-6.3 \%)\end{array}$ \\
\hline & & & Prime & Cine $(11.5 \%)$ & $\begin{array}{l}\text { Volando voy } \\
(8.4 \%) \\
\text { Cuarto Milenio } \\
(8.8 \%)\end{array}$ & $\begin{array}{l}\text { El peliculón } \\
(19.6 \%)\end{array}$ & $\begin{array}{l}\text { El objetivo }(11 \%) \\
\text { Vigilantes del } \\
\text { planeta }(4.2 \%)\end{array}$ \\
\hline
\end{tabular}


Week from October 15 to 21, 2018

\begin{tabular}{|c|c|c|c|c|c|c|}
\hline \multicolumn{4}{|r|}{ 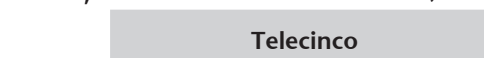 } & \multirow{2}{*}{$\begin{array}{c}\text { Cuatro } \\
\text { Program (share) }\end{array}$} & \multirow{2}{*}{$\begin{array}{c}\text { Antena } 3 \\
\text { Program (share) }\end{array}$} & \multirow{2}{*}{$\begin{array}{c}\text { La Sexta } \\
\text { Program (share) }\end{array}$} \\
\hline & & Slot & Program (share) & & & \\
\hline \multirow[b]{3}{*}{$\frac{\infty}{\delta}$} & \multirow[b]{3}{*}{ 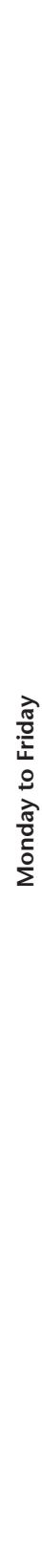 } & Morning & $\begin{array}{l}\text { El programa de AR } \\
(18.9 \%-19.7 \%) \\
\text { Ya es mediodía } \\
(11.1 \%-11.7 \%)\end{array}$ & $\begin{array}{l}\text { Alerta cobra } \\
\text { (3 chaps.) } \\
(3.4 \%-6 \%) \\
\text { MyHyV } \\
(3.9 \%-5.9 \%) \\
\text { El concurso del } \\
\text { año (6\%-7.3\%) }\end{array}$ & $\begin{array}{l}\text { Espejo público } \\
(10.9 \%-17.5 \%) \\
\text { Karlos Arguiñano } \\
(13.3 \%-13.8 \%) \\
\text { La ruleta } \\
(15.6 \%-19 \%)\end{array}$ & $\begin{array}{l}\text { Arusitys } \\
(4.1 \%-8.8 \%) \\
\text { Al rojo vivo } \\
(8.7 \%-16.9 \%)\end{array}$ \\
\hline & & Afternoon & $\begin{array}{l}\text { Sálvame diario } \\
(13.2 \%-19 \%) \\
\text { Pasapalabra } \\
(14.5 \%-17.1 \%)\end{array}$ & $\begin{array}{l}\text { Hawai } 5.0 \\
\text { ( } 2 \text { chaps.) } \\
(2.3 \%-3.8 \%) \\
\text { NCIS: Los Ángeles } \\
\text { ( } 2 \text { chaps.) } \\
(2.5 \%-4.4 \%)\end{array}$ & $\begin{array}{l}\text { Amar es para } \\
\text { siempre } \\
(12.2 \%-15 \%) \\
\text { El secreto de } \\
\text { Puente Viejo } \\
(13.4 \%-15 \%) \\
\text { Ahora caigo } \\
(16 \%-16.2 \%) \\
¡ B o o m ! \\
(16.6 \%-18.5 \%)\end{array}$ & $\begin{array}{l}\text { Zapeando } \\
(6.6 \%-7.3 \%) \\
\text { Más vale tarde } \\
(4.8 \%-8.5 \%)\end{array}$ \\
\hline & & $\begin{array}{l}\text { Access } \\
\text { and } \\
\text { Prime }\end{array}$ & $\begin{array}{l}\text { GH Vip: Última } \\
\text { hora (9\%) / } \\
\text { Vivir sin permiso } \\
\text { (18.3\%) (Mon) } \\
\text { GH Vip: límite } 48 \\
\text { horas } \\
\text { (16.3\%-27.9\%) } \\
\text { (Tue) } \\
\text { The good doctor } \\
\text { (2 chaps.) } \\
\text { (12.5\%-16.2\%) } \\
\text { (Wed) } \\
\text { GH Vip } \\
\text { (18.4\%-29.4\%) } \\
\text { (Thu) } \\
\text { Mi casa es la tuya } \\
\text { (10.8\%) (Fri) }\end{array}$ & $\begin{array}{l}\text { Bienvenidos a mi } \\
\text { hotel (3.5\%) / } \\
\text { First Dates (4.2\%) } \\
\text { / Ven a cenar } \\
\text { conmigo (5.9\%) } \\
\text { (Mon) } \\
\text { UEFA Nations } \\
\text { League } \\
\text { (3.5\%-8.9\%) / En } \\
\text { el punto de mira } \\
\text { (6.1\%) (Tue) } \\
\text { Bienvenidos a mi } \\
\text { hotel (4.3\%) / } \\
\text { First Dates (6\%) } \\
\text { / Cine (7.3\%) } \\
\text { (Wed) } \\
\text { Bienvenidos a mi } \\
\text { hotel (4.2\%) / } \\
\text { First Dates (6.2\%) } \\
\text { / Cine (4.9\%) } \\
\text { (Thu) } \\
\text { Bienvenidos a mi } \\
\text { hotel (2 chaps.) } \\
\text { (4.1\%-5.7\%) / } \\
\text { Cine (6.3\%) (Fri) }\end{array}$ & $\begin{array}{l}\text { El hormiguero } \\
3.0(11.9 \%) \\
\text { / Intercambio } \\
\text { consentido } \\
(10.1 \%) \text { (Mon) } \\
\text { El hormiguero } \\
3.0 \text { (14.2\%) / } \\
\text { Presunto culpable } \\
\text { (13.1\%) (Tue) } \\
\text { El hormiguero } \\
3.0(16 \%) / \text { Cine } \\
\text { (7.4\%) (Wed) } \\
\text { El hormiguero } 3.0 \\
\text { (14.9\%) / Cine } \\
\text { (6.8\%) (Thu) } \\
\text { Tu cara me suena } \\
\text { (12.6\%-22.1\%) } \\
\text { (Fri) }\end{array}$ & $\begin{array}{l}\text { El intermedio } \\
(7.8 \%) / \text { Cine } \\
(7.3 \%) \text { (Mon) } \\
\text { El intermedio } \\
(8.7 \%) \text { / Cine } \\
(3.8 \%) \text { (Tue) } \\
\text { El intermedio } \\
\text { (9.6\%) / ¿Te lo vas } \\
\text { a comer? (14.6\%) } \\
\text { (Wed) } \\
\text { La Sexta noticias } \\
\text { especial (7.9\%) } \\
\text { (Thu) } \\
\text { La Sexta columna } \\
\text { (5.5\%-8\%) } \\
\text { / Equipo de } \\
\text { investigación } \\
\text { (6.4\%) (Fri) }\end{array}$ \\
\hline
\end{tabular}




\begin{tabular}{|c|c|c|c|c|c|c|}
\hline 212 & & \multicolumn{2}{|c|}{ Telecinco } & \multirow{2}{*}{$\begin{array}{c}\text { Cuatro } \\
\text { Program (share) }\end{array}$} & \multirow{2}{*}{$\begin{array}{c}\text { Antena } 3 \\
\text { Program (share) }\end{array}$} & \multirow{2}{*}{$\begin{array}{c}\text { La Sexta } \\
\text { Program (share) }\end{array}$} \\
\hline$a$ & & Slot & Program (share) & & & \\
\hline \multirow[t]{6}{*}{ 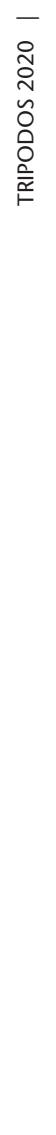 } & 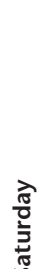 & Morning & $\begin{array}{l}\text { Más que coches } \\
(5.5 \%) \\
\text { Misión exclusiva } \\
(3.9 \%) \\
\text { Socialité by } \\
\text { Cazamariposas } \\
(9.3 \%)\end{array}$ & $\begin{array}{l}\text { El encantador de } \\
\text { perros }(6.3 \%) \\
\text { Callejeros viajeros } \\
\text { ( } 3 \text { chaps.) } \\
(6.2 \%-6.7 \%)\end{array}$ & $\begin{array}{l}\text { Centímetros } \\
\text { cúbicos }(4.5 \%) \\
\text { Los más... (4.1\%) } \\
\text { Ahora caigo } \\
\text { ( } 3 \text { reps.) } \\
(8.9 \%-10.1 \%)\end{array}$ & $\begin{array}{l}\text { Hoteles con } \\
\text { encanto ( } 2 \text { chaps.) } \\
(2.4 \%-2.9 \%) \\
\text { Equipo de } \\
\text { investigación } \\
\text { (3 reps.) } \\
(3.6 \%-5.2 \%)\end{array}$ \\
\hline & & Afternoon & Viva la vida (10\%) & $\begin{array}{l}\text { Cine (2 films) } \\
(5 \%-8.1 \%)\end{array}$ & $\begin{array}{l}\text { Multicine } \\
(12.5 \%-16.5 \%)\end{array}$ & $\begin{array}{l}\text { Cine (3 films) } \\
(3.1 \%-3.6 \%)\end{array}$ \\
\hline & & Prime & $\begin{array}{l}\text { Sábado deluxe } \\
(17.3 \%)\end{array}$ & $\begin{array}{l}\text { First Dates }(4.6 \%) \\
\text { / Cine }(5.9 \%)\end{array}$ & $\begin{array}{l}\text { Cine El peliculón } \\
(10.5 \%)\end{array}$ & $\begin{array}{l}\text { La Sexta noche } \\
(5.2 \%-8 \%)\end{array}$ \\
\hline & \multirow{3}{*}{ 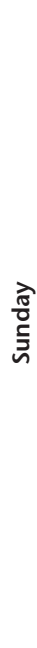 } & Morning & $\begin{array}{l}\text { Mi casa es la tuya } \\
\text { (rep.) }(7.1 \%) \\
\text { Socialité }(10.9 \%)\end{array}$ & $\begin{array}{l}\text { El encantador de } \\
\text { perros (3.6\%) } \\
\text { Callejeros viajeros } \\
\text { ( } 2 \text { chaps.) } \\
(4.4 \%-8.6 \%) \\
\text { Viajeros Cuatro } \\
(8.7 \%)\end{array}$ & $\begin{array}{l}\text { Tu cara me suena } \\
\text { (rep.) }(9.8 \%) \\
\text { Ahora caigo } \\
\text { ( } 2 \text { reps.) } \\
(10.6 \%-11 \%)\end{array}$ & $\begin{array}{l}\text { ¿Qué me pasa, } \\
\text { doctor? (2.6\%) } \\
\text { Zapeando (rep.) } \\
(3.1 \%) \\
\text { Equipo de } \\
\text { investigación } \\
\text { (2 reps.) } \\
(4.5 \%-5.3 \%)\end{array}$ \\
\hline & & Afternoon & $\begin{array}{l}\text { Viva la vida } \\
(10.4 \%)\end{array}$ & $\begin{array}{l}\text { Cine (2 films) } \\
(4.1 \%-6.8 \%)\end{array}$ & $\begin{array}{l}\text { Multicine } \\
(10.4 \%-15.2 \%)\end{array}$ & $\begin{array}{l}\text { Cine }(5.8 \%) \\
\text { Liarla Pardo } \\
(5.1 \%-9 \%)\end{array}$ \\
\hline & & Prime & $\begin{array}{l}\text { GH Vip: el debate } \\
(17.4 \%)\end{array}$ & $\begin{array}{l}\text { Volando voy } \\
(7.8 \%) / \text { Cuarto } \\
\text { Milenio } \\
(6.5 \%-8.6 \%)\end{array}$ & $\begin{array}{l}\text { El peliculón } \\
(11.4 \%)\end{array}$ & $\begin{array}{l}\text { Salvados } \\
(7.5 \%-10.8 \%) \\
\text { El objetivo }(5.3 \%) \\
\text { Expediente } \\
\text { Marlasca }(4.2 \%)\end{array}$ \\
\hline
\end{tabular}


Week from October 14 to 20, 2019 (Catalonia verdict week)

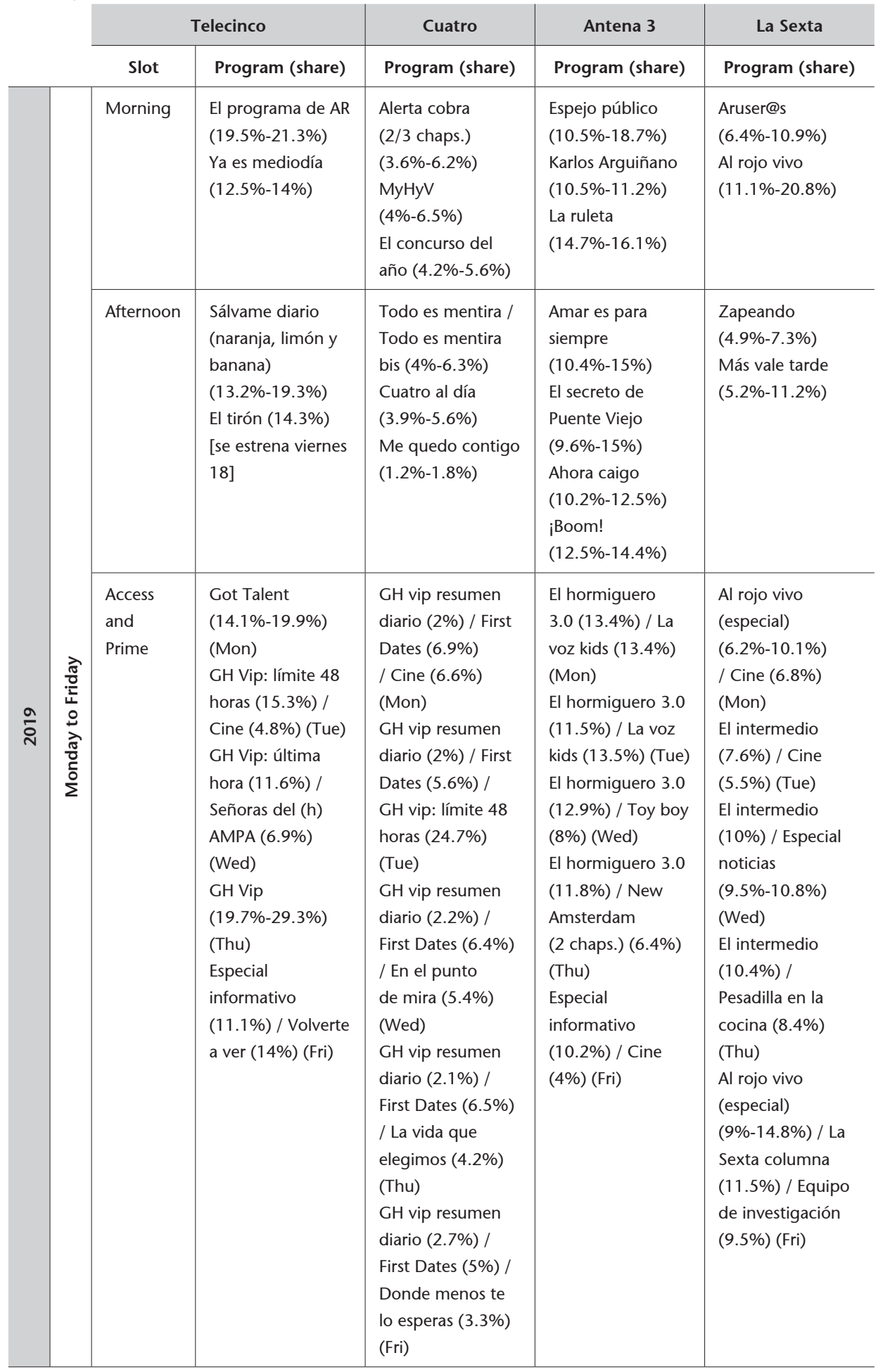




\begin{tabular}{|c|c|c|c|c|c|c|c|}
\hline \multirow[t]{6}{*}{ 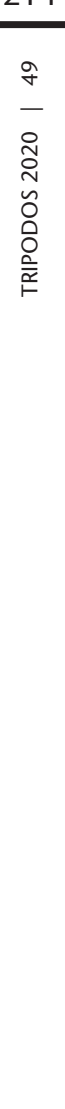 } & \multirow{6}{*}{ 융 } & \multirow{3}{*}{ 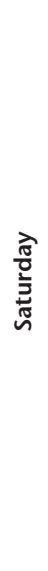 } & Morning & $\begin{array}{l}\text { Más que coches } \\
(6.1 \%) \\
\text { Got Talent. } \\
\text { Momentazos } \\
(6.4 \%) \\
\text { Socialité }(12.7 \%)\end{array}$ & $\begin{array}{l}\text { El encantador de } \\
\text { perros ( } 4.2 \%) \\
\text { Callejeros viajeros } \\
\text { ( } 2 \text { chaps.) } \\
(5.7 \%-7.5 \%) \\
\text { Viajeros Cuatro } \\
(6.5 \%)\end{array}$ & $\begin{array}{l}\text { Los más... } \\
(5.2 \%-5.3 \%) \\
\text { ¡Ahora caigo! } \\
\text { (7\%) } \\
\text { La voz kids (rep.) } \\
(6.9 \%)\end{array}$ & $\begin{array}{l}\text { Zapeando (rep.) } \\
(3.7 \%) \\
\text { Equipo de } \\
\text { investigación } \\
\text { (rep.) }(5.3 \%) \\
\text { La Sexta noticias } \\
\text { especial (11.8\%) }\end{array}$ \\
\hline & & & Afternoon & $\begin{array}{l}\text { Viva la vida } \\
(12.4 \%)\end{array}$ & $\begin{array}{l}\text { Cine (2 films) } \\
(5.8 \%-7.6 \%)\end{array}$ & $\begin{array}{l}\text { Multicine } \\
(10.8 \%-15.6 \%)\end{array}$ & $\begin{array}{l}\text { Cine }(5.3 \%) \\
\text { / Especial } \\
\text { informativo } \\
(6 \%-8.9 \%)\end{array}$ \\
\hline & & & Prime & $\begin{array}{l}\text { Sábado deluxe } \\
(15.4 \%)\end{array}$ & $\begin{array}{l}\text { First Dates }(5.2 \%) \\
\text { / Cine }(9.4 \%) / \\
\text { Cine }(7.3 \%)\end{array}$ & $\begin{array}{l}\text { Cine El peliculón } \\
(10.7 \%)\end{array}$ & $\begin{array}{l}\text { La Sexta noche } \\
(7.2 \%-11.5 \%)\end{array}$ \\
\hline & & \multirow{3}{*}{ 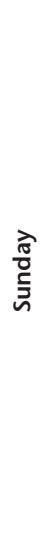 } & Morning & $\begin{array}{l}\text { Got talent (rep.) } \\
(14.4 \%) \\
\text { Socialité (15.1\%) }\end{array}$ & $\begin{array}{l}\text { El encantador de } \\
\text { perros }(5 \%) \\
\text { Callejeros viajeros } \\
\text { ( } 2 \text { chaps.) } \\
(5.2 \%-5.6 \%) \\
\text { Viajeros Cuatro } \\
(6.4 \%)\end{array}$ & $\begin{array}{l}\text { Los más... } \\
(4.2 \%-7.1 \%) \\
\text { Centímetros } \\
\text { cúbicos }(4.8 \%) \\
\text { ¡Ahora caigo! } \\
\text { (3 reps.) } \\
\text { (4.6\%-5.8\%) }\end{array}$ & $\begin{array}{l}\text { Bestial (1.5\%) } \\
\text { ¿Qué me pasa, } \\
\text { doctor? ( } 2.3 \%) \\
\text { Zapeando (rep.) } \\
(4 \%)\end{array}$ \\
\hline & & & Afternoon & $\begin{array}{l}\text { Viva la vida } \\
(10.9 \%)\end{array}$ & $\begin{array}{l}\text { Cine (2 films) } \\
(7.1 \%-7.6 \%)\end{array}$ & $\begin{array}{l}\text { Multicine } \\
\text { (10.5\%-14.6\%) }\end{array}$ & $\begin{array}{l}\text { Cine }(4.9 \%) \\
\text { Liarla Pardo } \\
(6.3 \%-10.7 \%)\end{array}$ \\
\hline & & & Prime & $\begin{array}{l}\text { GH Vip: el debate } \\
(20.1 \%)\end{array}$ & $\begin{array}{l}\text { Volando voy } \\
(6.4 \%) \text { / Cuarto } \\
\text { Milenio }(8 \%)\end{array}$ & $\begin{array}{l}\text { Cine El peliculón } \\
(14.9 \%)\end{array}$ & $\begin{array}{l}\text { Salvados }(8.3 \%) / \\
\text { El objetivo }(6.8 \%)\end{array}$ \\
\hline
\end{tabular}

